Ines Grgurina

Prva riječka hrvatska gimnazija

Frana Kurelca 1, HR-51000 Rijeka

inesgrgur14@gmail.com

\section{Luka Tidić}

Savičentska 6, HR-52100 Pula

lukatidic@hotmail.com

\title{
Učiteljska škola u Kastvu kroz dokumente Državnoga arhiva u Rijeci i Arhiva Prve riječke hrvatske gimnazije
}

Izvorni znanstveni rad | Original scientific paper

UDK 377.8(497.5 Kastav)(091)

Primljeno | Received: 23. XII. 2012.

\section{Izvadak}

Članak se bavi učiteljskom školom u Kastvu od njezina osnivanja 1906. do njezina preseljenja u Rijeku 1947. kroz dokumente kastavske općine koji su pronađeni u Državnom arhivu u Rijeci i školske arhive učiteljske škole koji se nalaze u Arhivu Prve riječke hrvatske gimnazije kao njezine sljednice. Opisani su i rad pripravnice u Kastvu, osnovane 1884., na temelju dokumenata iz Arhiva PRHG-a, borba kastavskih čelnika za dobivanje i zadržavanje učiteljske škole u svojoj općini te rad škole zabilježen u školskoj dokumentaciji. Dokumentacija ni u jednom arhivu nije potpuna. U Državnom arhivu u Rijeci nedostaju zapisnici kastavskoga općinskoga vijeća nakon 1912., a u Arhivu PRHG-a nalaze se samo neki zapisnici sjednica i dopisi pa sva razdoblja nisu ravnomjerno obrađena. Obradom objavljene literature i komparacijom podataka nastojat će se upotpuniti praznine u dokumentaciji. Zaključno će se sintetizirati utjecaj politike, promjene država i prosvjetne politike na rad škole.

\footnotetext{
Abstract

This article is about the school for teachers in Kastav from its founding in 1906 until it was moved to Rijeka in 1947 using documents from the county of Kastav found in the State's archives in Rijeka and the archives of the School for teachers found in the archives of First Croatian Grammar School of Rijeka, which was its successor. The work of interns founded in 1884 in Kastav is also described, based on the documents from the grammar school's archives, so is the battle of leaders of Kastav for getting and keeping the school for teachers in their county and school's work noted in school's records. There are records missing from the State's archives in Rijeka; records from Kastav county's council after 1912, and there are only several records of meetings and memos in the grammar school's archives, so not all periods
} 
are equally covered. By researching published literature and by comparing data, an attempt will be made to reconstruct the missing information. As a conclusion, an overview of the influence of politics, change of states and educational policies on the work of the school will be given.

Ključne riječi: hrvatski nacionalni pokret, Kastav, pripravnica, učiteljska škola, talijanska okupacija, Rapalski ugovor, prva petoljetka

Key words: Croatian national movement, Kastav, intern, school for teachers, Italian occupation, Treaty of Rapallo, prva petoljetka

\section{Uvodne napomene}

Markgrofovija Istra u vrijeme je austro-ugarske vladavine obuhvaćala istarski poluotok s kopnenim pojasom u zaleđu Ćićarije te otoke Krk, Cres i Lošinj, s ukupnom površinom od $4956 \mathrm{~km}^{2}$. Listopadskom diplomom iz 1860. i Veljačkim patentom iz 1861. dobila je zaseban zemaljski sabor (Istarski pokrajinski sabor) koji je zasjedao u Poreču. Istim je dokumentima u Beču osnovano zastupničko vijeće za cijelu Austro-Ugarsku s dva dijela: Velikaškim domom koji je imao status sličan senatu te zastupničkim domom ili Carevinskim vijećem. ${ }^{1}$ Istarski pokrajinski sabor zasnivao se na tzv. kurijalnom sustavu koji je uveden u svim pokrajinama zapadne polovice Monarhije i ostao nepromijenjen sve do 1907. Tek se od drugoga saziva Istarskoga sabora može reći da je političko djelovanje te ustanove imalo određenu dozu stabilnosti. Povećao se i broj hrvatskih i slovenskih zastupnika, birani su i hrvatski zastupnici u Carevinsko vijeće i Zemaljski odbor, a na izborima za općinska predstavništva počeli su upisivati prve uspjehe u gradovima središnje Istre. Početkom nove političke ere u Istri Hrvati još uvijek nisu imali prosvijećene ljude koji su mogli obavljati načelničku dužnost, a svećenici nisu mogli biti birani na taj položaj pa su redovito birani Talijani. ${ }^{2}$

1 Poreč je 1861. - 1897. bio sjedištem Istarskoga sabora i time kao upravno središte zamijenio Pazin koji je imao ulogu sjedišta Istarskoga okružja 1825. - 1860. Pula preuzima sjedište Istarskoga sabora 1898., a 1899. - 1910. sjedište je bilo u Kopru. Božo Milanović, Hrvatski narodni preporod u Istri, knj. I (1797-1882) (dalje: Hrvatski narodni preporod, I), Pazin 1967., 197-198, 201-204; Ante Cukrov, Izmedu obrazovanja denacionalizacije, Pula 2001., 37-40; Nevio Šetić, O povezanosti Istre sostalim hrvatskim zemljama. Naša sloga 1870-1915. (dalje: O povezanosti Istre), Zagreb 2005., 57-58.

2 Ante Cukrov je posebno izdvojio 1861. godinu jer su se dogodila tri vrlo važna događaja: Austrija se vratila parlamentarizmu, unutar političkih borbi u Istarskom saboru pojavili su se obrisi hrvatskoga nacionalnog pokreta i formuliran je prvi iredentistički program koji će odrediti u velikoj mjeri talijanskoaustrijske te hrvatsko-slovensko-talijanske odnose. Cukrov, Izmedu obrazovanja $i$ denacionalizacije, 33, 4145 
Od početka 1870-ih u Istru se proširio tzv. taborski pokret, pokret održavanja masovnih narodnih zborova. Istarski Hrvati su organizirali tabore po uzoru na Slovence koji su prvi takav u Istri organizirali 1870. u Kubedu, dok su Hrvati prvi organizirali 1871. na brdu sv. Mihovila nedaleko od Kastva. Motivacija pri organizaciji takve manifestacije bila je u činjenici da hrvatska etnička većina nije imala utjecaja na administraciju i bila je zakinuta u društvenom životu zbog relativno maloga broja obrazovanih ljudi i zbog slabe gospodarske moći.

Na izborima za Carevinsko vijeće 1873. uveden je novi izborni zakon koji je zadržao i dalje kurijalni sustav, ali je ukinuo biranje zastupnika preko zemaljskoga sabora i uveo izravne izbore preko izbornih fiducijara. Od početka parlamentarizma u Istri traje snažna borba Talijana s jedne strane te Hrvata i Slovenaca s druge strane. Talijansku političku stranu u Istri ohrabrivalo je i držanje Italije koja je vodila protuaustrijsku politiku i pokrenula pitanje „neoslobođenih krajeva“, uključujući i Istru. Stoga se u takvoj političkoj situaciji hrvatski nacionalni pokret udružio s pokretom primorskih Slovenaca na čelu s političkim društvom Edinost u Trstu. Sklapanjem sporazuma ovih dviju strana društvo Edinost je postalo 1878 . slovensko-hrvatsko društvo pa je svoju političku djelatnost proširilo i na istarske Hrvate. Zahvaljujući dobroj organizaciji društva otada se u Istri osjećao sustavniji politički rad, pa nacionalni pokret dobiva sva obilježja političke stranke. Ova je suradnja trajala do 1902., kada je u Pazinu osnovano Političko društvo za Hrvate i Slovence u Istri. ${ }^{3}$

U cestovnoj komunikaciji Istra je bila u velikim problemima jer je bila bez kvalitetnih kopnenih i pomorskih veza sve do sredine XIX. stoljeća. Unatoč činjenici da je Pazin cestovno spojen s Kastvom i preko njega Rijekom već 1785., trebalo je čekati sve do sredine XIX. st., kada je izgrađena cestovna mreža koja ga je spajala s glavnim naseljima na obali, od Trsta do Pule, a zatim i od Plomina duž Kvarnerskoga zaljeva. Pomorski se promet počeo jače razvijati od 1854., kada je uvedena stalna parobrodarska veza između Rijeke i Trsta, dok je željeznički promet uveden tek 1873. i 1876.

3 Gotovo istovremeno se javlja i iredentizam u Italiji, 1877., iako se ideja za sjedinjenje svih zemalja koje su se smatrale talijanskima javlja znatno ranije. I prije službenoga imenovanja pokreta bilo je poznato da određeni nacionalistički krugovi žele talijanske granice pomaknuti sve do Rijeke, Krka i Bakra. Stoga do 1860-ih iredentizam postupno buja i sve jasnije ocrtava svoje viđenje krajnjih istočnih granica. U Istri se razvijala slična politička misao među intelektualcima na zapadnoj obali, koja je stvorila teoretski antropološko-kulturološko-sociološki okvir pripajanja Slovenskoga primorja, Istre i Dalmacije Italiji. Istarski iredentizam u sprezi s onim u Italiji bio je čimbenik koji je uzburkao dotadašnje međunacionalne odnose u Istri. Svoj će vrhunac doseći u razdoblju talijanske vladavine Istrom 1918. - 1945. Cukrov, isto, 53, 66-89; Šetić, O povezanosti Istre, 64-67. 
Gospodarstvo je ponajviše zbog loših prometnih veza bilo slabo razvijeno te je utjecalo i na proizvodnju i na razmjenu dobara. Nešto je razvijenije bilo stočarstvo, a na istočnoj su se obali Istre razvili važni centri pomorstva i brodarstva na jedra. Gledajući prema pojedinim granama gospodarstva poljoprivreda je imala najveći broj radnika, a slijede je brodarstvo, ribarstvo, ostali obrti te trgovina. Tijekom druge polovice XIX. stoljeća hrvatsko i slovensko selo, pogotovo u zapadnoj i sjeverozapadnoj Istri, bilo je ovisno o talijanskim gradovima. Među prvim velikim gospodarskim problemima bilo je nepostojanje hipotekarnih zavoda pa su se seljaci morali zaduživati kod talijanskih trgovaca kako bi mogli platiti rasteretne dugove iz 1848., a kasnije i ublažiti krizu iz 1870. zbog pepelnice, bolesti koja je zahvatila vinograde. Poslije 1868. provedena je reorganizacija općina prema zakonu kojim je određeno da se općine koje nemaju uvjete za samostalno upravljanje moraju pripojiti gospodarski jačim općinama. Stoga je situacija išla u korist talijanskih gradova, čije je gospodarstvo prodiralo na selo i širilo svoj utjecaj. Istarsko je gospodarstvo posljednjih desetljeća XIX. st. doživjelo promjene koje su ostavile dublji trag u društvenim i nacionalnim odnosima te na području politike. Trst, Pula i Rijeka, tri velika grada koja okružuju istarski poluotok na njegovim rubnim točkama, doživjeli su velik uspon u to doba pa su Istru povukli u procese kapitalističkih odnosa i pridonijeli prodoru kapitalizma na selo. ${ }^{4}$

Uz ekonomsku problematiku, koja je većinsko hrvatsko i slovensko stanovništvo stavljala u neravnopravan položaj prema talijanskom, potrebno je napomenuti da su socijalne razlike između sela i grada bile vrlo izražene. Ovakva je situacija dodatno pojačana i etničkom oprekom jer je najveći dio Talijana živio u gradovima u sjeverozapadnom i zapadnom dijelu Istre dok su Hrvati i Slovenci najvećim dijelom živjeli na selu u unutrašnjosti Istre. Među istarskim Hrvatima bilo je nešto malo građana (pučana) u gradićima istočne Istre oko Kvarnera (Kastav, Volosko, Lovran i Vrbnik na Krku). ${ }^{5}$ Kapitalizam koji je prodirao u istarsko selo zaoštravao je nacionalne odnose, ali je svojim razvojem jačao, osim talijanskoga, i hrvatsko građanstvo te radništvo. Prema kraju XIX. st. rastao je broj hrvatskih trgovaca, činov-

4 Trst je kao glavna trgovačka izvozna i uvozna luka uživao veliku brigu austrijske vlade. Pula je posebnu važnost za Istru (kao i za cijelu državu) imala kao glavna ratna luka. Zahvaljujući tomu u Istri je 1876. u promet puštena željeznica koja je povezivala Istru s ostalim austrijskim predjelima. Rijeka je bilježila velik gospodarski uspon nakon 1867., kada je ugarska vlada odlučila u njoj razviti veliku trgovačku luku za cjelokupnu ugarsku polovicu Monarhije. Jaroslav Šidak, Povijest hrvatskog naroda g. 1860-1914. (dalje: Povijest hrvatskog naroda), Zagreb 1968., 180-182; Šetić, isto, 62-63, 70-71.

5 Milanović, Hrvatski narodni preporod, I, 198-201; Šidak, Povijest hrvatskog naroda, 10-13, 113. 
nika, učitelja, odvjetnika, obrtnika i radnika, dok se u hrvatskim selima postupno izdvajaju srednji i imućniji seljaci koji su postali i trgovci pa su ušli u konkurenciju s talijanskim trgovcima. ${ }^{6}$

Radnički pokret u Istri svoje početke može zahvaliti gradovima i mjestima gdje su postojale veće ili manje koncentracije radništva poput Pule, Krapna, Labina, Rovinja, Izole i Milja. Prvi poticaji za stvaranje radništva u Istri dolaze iz Trsta koji je slovio kao jak centar talijanskoga i slovenskoga radništva. Međutim, tek je u razdoblju 1895. - 1897. započeo sustavniji i intenzivniji rad na širenju radničkoga pokreta i socijalističke misli. Iako su se pokušavale osnovati jedinstvene radničke organizacije, nisu bile dugoga vijeka jer su vlasti ograničavale njihov rad i zabranjivale ih prije negoli su uspjele proširiti svoje djelovanje na Istru. Tako je u početku jedinoga uspjeha u širenju radničkoga pokreta imala Talijanska socijaldemokratska stranka u Puli. ${ }^{7}$

Usporedno s političkim životom Istre počeo se razvijati i hrvatski nacionalni pokret koji je započeo mnogo kasnije nego u većini drugih hrvatskih zemalja. On se u Istri odvijao potpuno drugačije zbog povijesnih razloga koji su uvjetovali drugačije društvene, gospodarske i političke prilike. Druga polovica XIX. st. u Istri je obilježena zaoštravanjem odnosa između sela i grada te međunacionalnih odnosa. Zbog nerazvijenoga hrvatskog i slovenskog građanstva hrvatski i slovenski nacionalni pokret u Istri započinje tek šezdesetih godina XIX. st., a nosioci su bili svećenici, koji su najčešće bili jedini školovani ljudi na istarskom selu. Od 1860-ih pa sve do Prvoga svjetskog rata sadržaj nacionalnoga pokreta u Istri svodi se na sljedeća pitanja: borbu za nacionalni jezik i njegovu upotrebu u školama i javnim službama, borbu za očuvanje lokalne uprave te preuzimanje općinskih uprava, borbu za veći utjecaj i ravnopravnost u Istarskom saboru, borbu za ravnopravnost u Carevinskom vijeću, borbu za sjedinjenje Istre i Dalmacije s Hrvatskom te osnivanje zajedničke države južnih Slavena unutar Austro-Ugarske.

Među prvim ljudima iz redova svećenstva koji su se uključili u hrvatski nacionalni pokret na području Istre bio je Juraj Dobrila, koji se još za školovanja upoznao s idejama ilirskoga pokreta. Iako je Dobrila po svojim socijalnim i religijskim shvaćanjima bio konzervativan, u političkom je smislu odlučno zastupao interese svoje zemlje, a posebno njezinoga sla-

6 Šidak, isto, 182.

7 Isto, 207. 
venskoga stanovništva. Osim na političkom i crkvenom planu bio je vrlo aktivan i na literarnom te izdavačkom planu. Već 1854. u Trstu je objavio molitvenik Otče budi volja tvoja!, a 1869. i 1870. objavio je kalendare na hrvatskom jeziku pod nazivom Istran. Bio je i glavnim pokretačem lista Naša sloga (izlazio 1870. - 1915.), čime je dodatno pridonio razvoju hrvatskoga nacionalnoga pokreta u Istri. Za razliku od drugih preporodnih listova, Naša sloga se izravno obraćala seljaku pa su stil i sadržaj prilagođeni tom društvenom sloju. Među istarskim Hrvatima i Slovencima prve se čitaonice otvaraju tek 1860-ih i 1870-ih u Kastvu, Puli, Dekanima, Vrbniku, Puntu i Kopru, dok su Talijani prvu javnu knjižnicu otvorili u Kopru već $1760 .^{8}$

U 1880-im se generacija koja je u javnom životu stasala dvadesetak godina prije polako prorjeđuje i nestaje $\mathrm{s}$ istarske političke scene. $\mathrm{U}$ to je vrijeme vrlo brzo vodeću ulogu preuzela mlađa generacija na čelu s Matkom Mandićem, koji je 1883. postao odgovornim urednikom Naše sloge, Matkom Laginjom, koji je već 1883. postao zastupnikom Istarskoga sabora te Vjekoslavom Spinčićem, koji je već tada bilježio političke nastupe. Smjena generacije dovela je do promjene i političkih nazora koji su sada bili liberalniji, iako je bilo i svećenika među njima. Međutim, najveća je promjena bila prelazak od narodnjačke prema pravaškoj politici pod utjecanjem školovanja u hrvatskim školama u Rijeci i Senju. Istarski pravaši nisu mogli dosljedno pratiti ideje Ante Starčevića zbog situacije na Poluotoku, ali su zato unijeli više borbenosti u hrvatske političke redove. Politika talijanske buržoazije također je doživjela promjene, pogotovo nakon Berlinskoga kongresa 1878., jer je slabljenjem dominantnoga položaja u Istri morala odabrati novu taktiku. U svom je radu mogla računati na potporu talijanske vlade, koja je unatoč suzbijanju iredentizma davala potporu širenja talijanstva u Istri. Stoga je talijansko građanstvo 1884. osnovalo političku organizaciju Società politica istriana s programom širenja talijanske nacionalne ideje, civilizacije i kul-

8 Osobno se zalagao za gospodarsko podizanje zemlje, ublažavanje postupaka prilikom zapljene zbog neplaćenoga poreza, melioraciju zemljišta i dr., a s ostalim hrvatskim zastupnicima nastavio je borbu za dvojezičnost u Saboru i ostalim segmentima javnoga života. Međutim, nije uspio spriječiti uvođenje nastave na talijanskom jeziku u pučke škole u naseljima s većinskim slavenskim stanovništvom. Šidak, Povijest hrvatskog naroda, 61-62; Cukrov, Izmedu obrazovanja i denacionalizacije, 34-36, 52-54; Šetić, O povezanosti Istre, 63. 
ture..$^{9}$ Osim ove organizacije isti je cilj imalo i društvo Pro patria, koje od 1886. pomaže osnivanje talijanskih škola u Istri. ${ }^{10}$

Hrvatski narodni preporod u Istri u to je vrijeme bio mnogo jači nego što su pokazali izbori za Carevinsko vijeće 1885. Hrvatske su čitaonice ubrzano otvarane u gradićima, manjim mjestima i selima. Kastav 1886. podiže prvi Narodni dom u Istri, 1886. i 1887. u pazinskoj općini i u Buzetu za načelnika je prvi put izabran hrvatski seljak, a u ruke Narodne stranke dolaze gotovo sve općine na kvarnerskim otocima i na Liburniji, da bi nešto poslije i gotovo sve općine jugoistočne i središnje Istre promijenile političku strukturu. U Istarskom su saboru 1884. hrvatski i slovenski zastupnici osnovali Hrvatsko-slovenski klub s ciljem očuvanja i buđenja nacionalne svijesti, borbe za ravnopravnost jezika i sudjelovanja u državnoj i pokrajinskoj upravi, stvaranja boljih gospodarskih uvjeta, brige za podizanje škola te proširenja izbornoga prava za općinska predstavništva i Pokrajinski sabor. Jačanje hrvatskoga nacionalnog pokreta nailazio je na ogorčenu reakciju talijanske strane jer je u njemu vidjela opasnost za svoje privilegirane pozicije. Početkom 1890-ih u Ljubljani je održan sastanak slovenskih zastupnika svih slovenskih krajeva i hrvatskih zastupnika iz Istre na kojem je izglasana rezolucija. Na glavnoj skupštini političkoga društva Edinost u Trstu odlučeno je da se poradi na osnivanju hrvatsko-slovenskoga kluba koji bi u Carevinskom vijeću surađivao s onim klubom koji bi podupirao bar provođenje odluka posljednjega ljubljanskog sastanka, ali i na tom je polju bilo problema jer je Klub otežano djelovao. ${ }^{11}$

Krajem XIX. i početkom XX. stoljeća razvile su se nove političke prilike u Istri, koje su počele mijenjati do tada jedinstvenu sliku istarskoga političkog života sa strogom podjelom na dvije protivničke nacionalne stranke. Narodna stranka nije više bila u tolikoj mjeri kompaktna koliko

9 Società politica istriana je bila politička organizacija poslije poznata kao Talijanska liberalna stranka. Utemeljena je na inicijativu Francesca Costantinija 1884. u Pazinu. Zahvaljujući izbornom sustavu prema kojem je većem poreznom opterećenju odgovarao veći politički utjecaj, Talijanska liberalna stranka je monopolizirala moć i u gradovima i u Istarskom saboru. Osnivanje stranke talijanskih socijalnih kršćana znatno je oslabilo Talijansku liberalnu stranku. Međutim, Političko društvo za Hrvate i Slovence u Istri i Talijanska liberalna stranka postigli su 1908. dogovor o podjeli izbornih jedinica, čime su marginalizirali ostale stranke i osigurali Talijanskoj liberalnoj stranci većinu u Istarskom saboru. Te dvije stranke nisu uspijevale surađivati pa su blokirale rad Sabora sve do Prvoga svjetskog rata. Stranku je raspustila austrijska vlast 1915. Vanni D’Alessio, „Società politica istriana (SPI, Istarsko političko društvo)“, Miroslav Bertoša - Robert Matijašić (ur.), Istarska enciklopedija, Zagreb 2005., 735.

10 Šidak, Povijest hrvatskog naroda, 182-184; Šetić, O povezanosti Istre, 67-68.

11 U rezoluciji se zahtijevalo postavljanje činovnika koji govore slovenski ili hrvatski, podizanje slovenskih i hrvatskih škola, osnivanje slovenske gimnazije u Celju, Gorici i Trstu te hrvatske gimnazije u Pazinu, a u Ljubljani osnivanje pravnoga fakulteta sa slovenskim i hrvatskim nastavnim jezikom. Šidak, isto, 184-187; Šetić, isto, 68-70. 
desetak godina prije pa je Talijanska liberalna stranka pokušavala iskoristiti priliku njezine slabe aktivnosti i opadanja popularnosti. U Istarskom je saboru Talijanska liberalna stranka dobila na snazi pa je odbijala mogućnost kompromisa o pitanju jezika. U novom sazivu Istarskoga sabora od 1896. Talijanska liberalna stranka uspjela je poništiti izbor trojice zastupnika te je odbijala birati članove hrvatsko-slovenske stranke u Pokrajinski odbor i saborska povjerenstva. Tome je pridodala odluku o smanjenju proračuna za podizanje novih škola, kojom je nastojala pogoditi hrvatsko i slovensko školstvo. Stoga je austrijska vlada pokušala naći način suradnje dvije političke strane u Istri, ali stanje je ostalo gotovo nepromijenjeno. ${ }^{12}$

Već je početkom XX. st. hrvatsko-slovenska stranka prebrodila krizu, koja nije zahvatila cijelu Istru pa se stranka nalazila u centru borbe za nacionalnu ravnopravnost i slobodu. Ovakvom političkom razvoju uvelike je pripomogla i demokratizacija izbornoga sustava u Austriji koja je išla u prilog istarskim Hrvatima i Slovencima. Talijanska liberalna stranka ponovno se nije htjela pomiriti s ravnopravnošću pa je u Istarskom saboru početkom XX. st. ponovno odbijala izbor hrvatskih i slovenskih zastupnika u saborske odbore te opstruirala njihov rad. Zbog toga su propadali svi pokušaji sklapanja sporazuma. Tih se godina osjećala promjena u vladinoj politici prema Gorici, Trstu i Istri, koja se očitovala u nepovjerenju prema Italiji, dok je više simpatija pokazivala za potrebe Slovenaca i Hrvata, prema Talijanskoj kršćansko-socijalnoj te Talijanskoj socijaldemokratskoj stranci. Od 1905. odlučnije su nastupale snage koje su vodile borbu za demokratizaciju zemlje. Na prvom su mjestu zahtijevale reformiranje izbornoga zakona za Carevinsko vijeće, što bi lančano dovelo i do reforme izbornoga zakona za Istarski sabor. Nakon postignutoga kompromisa uslijedila je izborna kampanja i izbori za Carevinsko vijeće koji su pokazali da su se okolnosti promijenile na štetu Talijanske liberalne stranke, dok je hrvatsko-slovenska stranka ojačala. ${ }^{13}$

\section{Borba za nastavu na hrvatskom jeziku u Istri}

Još je u vrijeme Jurja Dobrile bilo jasno političkim vođama da je pitanje nastavnoga jezika među najvažnijim pa se oko toga na svim razinama, od Istarskoga sabora do novina, vodila snažna borba. Ovome treba pridodati

12 Šidak, isto, 188-192.

13 Isto, 235-236; Šetić, O povezanosti Istre, 71-77. 
da je talijanska strana u Istarskom saboru bila snažnija pa su njezino naprezanje donekle kočili državni školski zakoni doneseni za cijelu Austro-Ugarsku. Službenim je jezikom 1861. postao talijanski, a hrvatsko školstvo u Istri najviše je pogodilo zakon iz 1869., kojim se škole oduzimaju iz nadležnosti klera. Ovakva je situacija najviše pogodila hrvatske i slovenske škole jer su imale podršku Crkve. Stoga se borba za hrvatske i slovenske škole prenijela iz sabora u općine. Preporoditeljske ideje najbrže su se ukorijenile u istočnoj Istri, kamo dolaze iz susjedne Hrvatske. Zakonom iz 1875. došlo je do promjene u sastavu pokrajinskoga i mjesnoga školskog vijeća, dok je zakonom iz 1872. odlučeno da će učitelje imenovati pokrajinska uprava u Poreču. Kako je školske nadzornike imenovalo C. i kr. namjesništvo, među njima je bilo i Hrvata i Slovenaca. ${ }^{14}$

Talijansko je građanstvo imalo premoć na gospodarskom, kulturnom i političkom polju, što mu je omogućilo širenje talijanskoga jezika i preko njegovih etničkih granica. Zato se hrvatsko i slovensko školstvo tome teško moglo oduprijeti, pogotovo nakon laiciziranja školstva od kojega se jedva oporavilo. Već početkom 1904. vlada je zatražila od slovenskih i hrvatskih stranaka da se izjasne o pitanju osnivanja talijanskoga sveučilišta. Predstavnici su odgovorili da će pristati ako se sveučilište osnuje u dijelu Austrijskoga primorja gdje su Talijani u većini ako se osnuje slovensko u Ljubljani. Inzistirali su i na činjenici da sveučilište mora biti dvojezično ako se osniva na području gdje su Slaveni većinski narod. Postavili su i zahtjev o osnivanju većega broja novih hrvatskih i slovenskih osnovnih i srednjih škola. Zahtjevi hrvatskih i slovenskih stranaka izneseni u spomenici bili su dovoljni da talijanska liberalna stranka odustane od pregovora. ${ }^{15}$

Iako je 1883. izglasan zakon o ravnopravnosti hrvatskoga i slovenskoga jezika na sudovima u Istri, u praksi ta dva jezika nisu imala ravnopravan status s talijanskim, čemu je među uzrocima bio i nedostatak školovane inteligencije na tim jezicima. Stoga jedna od najvažnijih zadaća hrvatskih političara u Istri u drugoj polovici XIX. st. postaje borba za nacionalni jezik, tj. za njegovu uporabu u školama i ravnopravnost s drugim jezicima (tali-

14. Milanović, Hrvatski narodni preporod, I, 289-291; Šidak, isto, 63.

15 Šidak, isto, 235. 
janskim i njemačkim) u javnim službama. ${ }^{16}$ Presudnu važnost za realizaciju te zadaće imale su učiteljske škole jer ako nema školovanih učitelja koji će podučavati djecu na hrvatskom jeziku, neće biti ni budućih činovnika ni intelektualaca koji mogu raditi i djelovati na tom jeziku. ${ }^{17}$

Pučka škola postaje obavezna u Monarhiji temeljem članka 59. Državnoga školskoga zakona od 14. svibnja 1861. i članka 1. Zemaljskoga zakona za Istru od 30. ožujka 1870. Za ustroj javnih pučkih škola morale su se pobrinuti pokrajine i općine „uz odgovornost c. kr. vlade koja ima bdjeti nad izvršenjem zakona. Ipak u pokrajini Istri 1898. ima oko 17000 djece, hrvatske i slovenske, koja je ne pohađaju jer je nemaju“, ${ }^{18}$ što je više od 57 \% školskih obveznika u Istri. Od 1870. bilo je predviđeno zakonom da djeca moraju pohađati školu od 6. do 12. godine života s obvezom pohađanja dodatnih dviju godina večernjih predavanja. Osim toga, odlučeno je da se škole trebaju podizati na mjestima koja su udaljena najviše jedan sat hoda na području gdje će škola u prosjeku skupiti oko 40 učenika. Međutim, istarski su Slovenci, poput Hrvata, imali određenih organizacijskih problema pa je Istarskom saboru dopušteno prilagođavanje u dužini

16 U tom je razdoblju nacionalna borba bila sve složenija i oštrija, a glavna se borba vodila za škole i jezik. Stanje hrvatskoga i slovenskoga školstva se donekle popravilo, ali talijanske škole su i dalje bile dominantne sa 181 razredom u 60 osnovnih škola u odnosu prema 105 razreda u 89 hrvatskih i slovenskih škola. Prema kraju XIX. st. zaoštravala se i borba za jezik jer je hrvatsko-slovenska stranka neprestano pokretala pitanje jednakopravnosti pokrajinskih jezika u državnim uredima, na sudovima i u cjelokupnom javnom životu. Vlada je, unatoč želji skidanja tog pitanja s dnevnoga reda, bila neodlučna pa je izazivala nezadovoljstvo s obje strane. Milanović, Hrvatski narodni preporod, I, 290; Cukrov, Izmedu obrazovanja $i$ denacionalizacije, 35 .

17 O prilikama u Istri, hrvatskom nacionalnom pokretu i školstvu pisali su između ostalih Mijo Mirković, „O sadržaju i smislu narodnog preporoda u Istri (1861-1914.)“, Jadranski zbornik, 5, 1961., 5-35; Mate Demarin, „O povijesnoj stazi hrvatskog školstva u Istri“, Pedagoški rad, 9-10, 1968., 410-423; Jakša Ravlić (ur.), Hrvatski narodni preporod u Dalmaciji i Istri, Zagreb 1969.; Božo Milanović, Hrvatski narodni preporod, I; isti, Hrvatski narodni preporod u Istri, knj. II (1883-1947) (dalje: Hrvatski narodni preporod, II), Pazin 1973.; Josip Ćiković, ,»Naša sloga« o školstvu Istre (1870-1879)“, Zbornik za povijest školstva i prosvjete, 24, 1991., 105-109; Mirjana Strčić - Petar Strčić, Hrvatski istarski trolist, Rijeka 1996.; Dragovan Šepić, Hrvatski pokret u Istri u XIX. i na početku XX. stoljeća, Račice 2004.; Nevio Šetić, O povezanosti Istre sostalim hrvatskim zemljama - Naša Sloga 1870. - 1915., Zagreb 2005.; isti, Staleška društva i časopisi hrvatskog učiteljstva u Istri 1891.-1914., Zagreb 2010.; Zlatan Varelija, Narodnjačka krv u temeljima hrvatske škole: sto godina hrvatskog školstva 1911. - 2011., Umag 2011 .; Luka Tidić, „Problematika hrvatskoga školstva u Istri na stranicama Naše sloge (1870. - 1880.)“, Histria, 2, 2012., 147-171. Opsežno djelo o školstvu u Istri napisao je Ante Cukrov, Izmedu obrazovanja $i$ denacionalizacije. O prilikama u Kastvu i školstvu u Kastvu pisali su u Zborniku Kastavštine Manon Giron, „90 godina od preseljenja Učiteljske škole u Kastav“, V, 1997., 43-58; Antun Giron, „Gospodarske nedaće općine Kastav nakon razgraničenja između Kraljevine SHS i Kraljevine Italije“, V, 1997., 59-71; Agneza Szabo, „Grad Kastav u žarištu politike Hrvatskoga sabora u vrijeme stvaranja Dualističke Monarhije 1861. - 1868.“, XVII, 2009., 13-24; Željko Klaić, „Prilog polemici o uspostavljanju Carske kraljevske učiteljske škole u Kastvu“, XVII, 2009., 25-54. Treba spomenuti i spomen-knjigu 50 godina rada Učiteljske škole u Kastvu i Rijeci 1906-1956 (dalje: 50 godina rada Uciteljske škole), spomenica, uži redakcioni odbor Vilko Grbac, Vinko Antić i Zvonimir Matagić, Rijeka 1956. U knjizi nisu navedena imena autorā poglavljā, a nema ni znanstvenoga aparata (podrubnih bilježaka).

18 Državni arhiv u Rijeci (dalje: HR-DAR), JU-37-194, VIIa, dopis kastavskoga općinskog glavara gosp. Franje Savera Munića Visokoj c. kr. vladi protiv otvaranja talijanske realne gimnazije u Pazinu od 20. VII. 1899., spis br. 2615. 
nastave zbog nedostatka učitelja i školskoga prostora. Kakvo je bilo stanje u istarskim školama 1860. - 1870. može se prosuditi samo prema broju učitelja u školskoj godini 1869./1870., kada je bilo ukupno jedva preko 200 učitelja, svjetovnjaka i svećenika, ali svjetovni učitelji tada još nisu imali ispit osposobljenosti. Stoga je vlada pokušala povećati broj učitelja i dodjeljivanjem stipendija obvezujući buduće učitelje da moraju poučavati barem šest godina u pučkim školama. Sve do smjene prve političke generacije istarskih Hrvata i Slovenaca u javnosti su bila često pokretana pitanja o broju i stanju škola te jeziku u školama i iznošena izvješća na svim političkim razinama. ${ }^{19}$

U školskoj godini 1882./1883. u Istri je bilo 60 talijanskih i 56 hrvatsko-slovenskih škola uz 156 talijanskih i 56- 72 hrvatska i slovenska učitelja. Do 1885. Talijani su u velikoj mjeri pokušavali „potalijančiti“ hrvatske škole u istočnoj Istri, što dokazuje i govor Dinka Vitezića u Carevinskom vijeću. Uza sve postojeće probleme Istarski je sabor 1896. izglasao taksu u visini od tri forinte po godini za svako dijete ako nije bilo zakonski oslobođeno od škole. Plaćanje ove takse tražilo se već za školsku godinu 1905./1906., što je uzrujalo i talijanske seljake te siromahe. Zbog toga što nalog nije došao na vrijeme i zbog poteškoća u plaćanju, političko društvo Edinost pokrenulo je akciju prikupljanja općinskih potpisa kako bi se provedba naplate takse odgodila barem za godinu dana. ${ }^{20}$

U Trstu je postojalo Pokrajinsko ili Zemaljsko školsko vijeće za Istru kojemu je predsjednik bio c. i kr. namjesnik. Istarski je sabor imao pravo na dva člana koji su ga predstavljali u tom vijeću. Nad osnovnim školama imalo je izvršnu vlast pa je moglo odlučivati o otvaranju novih pučkih škola te o namještanju i premještanju učitelja nakon savjetovanja s Istarskim saborom. Uz Pokrajinsko školsko vijeće za Istru postojala su i kotarska te općinska školska vijeća koja su uglavnom iznosila prijedloge i savjete nadležnom Pokrajinskom školskom vijeću. Kotarskim i općinskim školskim vijećima predsjedavali su kotarski poglavar odnosno općinski načelnik. ${ }^{21}$

19 Milan Marušič je u radu „Slovenska šola v Istri“ iznio podatke bečke Statističke centralne komisije iz školske godine 1864./1865. o broju slovenskih škola u slovenskom dijelu Istre, njihovoj organizaciji i stanju. Iako su škole vodili svećenici, u školama se uz vjeronauk podučavalo čitanje, pisanje, matematika, govorne vježbe slovenskoga jezika, vrtlarstvo, zemljopis i poljoprivredu. Već je 1862. tršćansko namjesništvo donijelo odluku o održavanju nastave na jeziku učenika. Milanović, Hrvatski narodni preporod, I, 291-295; Šidak, Povijest hrvatskog naroda, 188; Milan Marušič, „Slovenska šola v Istri“, Annales, 6, 1995., 182-183.

20 Milanović, Hrvatski narodni preporod, II, 12, 342-345, 360.

21 Isto, 12, 341-342. 
Uz Pazin kao centar narodnoga preporoda, važnu ulogu ima i Kastav, u kojem je još 1866. otvoren prvi Narodni dom i prva hrvatska čitaonica u Istri, a među uglednije osobe u istarskom političkom životu krajem XIX. st. ubrajaju se i Kastavci Matko Laginja, Vjekoslav Spinčić, Matko Mandić ${ }^{22}$ i Ante Dukić, koji je poslije izbora 1889. izabran za potpredsjednika Istarskoga sabora. Od pedesetih godina XIX. st. nadalje u Kastvu je djelovala hrvatska škola, ako izuzmemo razdoblje apsolutizma, kada se i u njoj forsirala germanizacija. ${ }^{23} \mathrm{U}$ arhivskim spisima iz 1899. nalazi se više dopisa ${ }^{24}$ u kojima općinski glavar Kazimir Jelušić (Kastav je bio općina u sastavu kotara Volosko) vraća dopise poslane iz poreznoga ureda u Voloskom jer su pisani njemačkim ili talijanskim jezikom pa ih narod ne razumije, čak i pod prijetnjom novčane kazne, a ured u Voloskom vraćao mu ih je uz napomenu da nemaju ljudi koji znaju dopise napisati na hrvatskom jeziku. ${ }^{25}$ Razumljivo je stoga nastojanje Kastavske općine da dobije učiteljsku školu.

\section{Pripravnica}

Godine 1870. dolazi do reorganizacije školstva u Monarhiji. Kako su potrebe u školstvu tada bile velike, austrijjske su vlasti nastojale u Istri organizirati jednu solidnu učiteljsku školu s dobro plaćenim nastavnicima i s najmanje 20 stipendija godišnje za učenike. Prva učiteljska škola otvorena je u Rovinju 3. studenoga 1870. Reorganizirana škola imala je spremati učitelje za talijanske i „ilirske“ škole ili za škole u kojima se uči i jedan i drugi jezik. Talijanski jezik određen je kao nastavni, ali je omogućeno kandidatima koji se spremaju za ilirske osnovne škole da uče ilirski jezik kao obligatni predmet. Te prve godine u školu se upisalo sedam kandidata, a tijekom prvoga semestra dvojica su otpala. Od petorice kandidata koji su završili školsku godinu samo jedan nije bio rodom iz Rovinja i niti jedan se nije javio za ilirski jezik pa se može pretpostaviti da su bili Talijani. Austrijske vlasti su pričekale da

22 U Kastav se napredne ideje šire iz obližnje Rijeke, gdje su se poneki Kastavci školovali u gimnaziji i gdje su izlazili narodni listovi te se tako sveza s hrvatskim pokretom uvijek održavala. F. Sloković, „Narodne čitaonice u Istri“, Hrvatska čitaonička društva u Istri u 19. i početkom 20. stoljeća, prir. Bruno Dobrić, Pula Pazin 1993., 89.

23 U školu u Kastvu šalju roditelji svoju djecu i iz udaljenih krajeva. Tako je otac, trgovac, poslao mladoga Eugena Kumičića u Kastav u osnovnu školu da bi mogao kasnije polaziti gimnaziju. I sam biskup Juraj Dobrila šalje svoje rođake, braću Červare u kastavsku školu. 50 godina rada Učiteljske škole, 33.

24 HR-DAR, JU-37-198, dopisi općinskoga glavara Franje Savera Munića od 29. XI. 1898., spis br. 2615 i od 21. XII. 1898., spis br. 22 .

25 HR-DAR, JU-37-194, F. S. Munić u dopisu br. 191 od 22. X. 1891. navodi da cijela Općina Kastav ima preko 15500 ljudi. Od njih samo 30 nisu hrvatske narodnosti i u svakodnevnom životu Kastavci se služe isključivo hrvatskim jezikom. 
vide kako će se razviti novoorganizirana učiteljska škola i kakav će učinak imati. Budući da je bilo premalo đaka, riješeno je da se škola preseli u Kopar ili Pazin. Kopar je bio u prednosti jer je imao potpunu gimnaziju. Pazin je imao doduše samo nižu nepotpunu gimnaziju, ali je bio povoljniji zbog zemljopisnoga smještaja u središtu Istre, a pored toga je imao osmoricu učenika koji zbog siromaštva nisu mogli nastaviti školovanje pa je bilo nade da bi se ova osmorica mogla pridobiti za upis u učiteljsku školu. Konačno je ipak riješeno da se učiteljska škola premjesti u Kopar zajedno s vježbaonicom. ${ }^{26}$ U školskoj godini 1872./1873. otvorena je Muška učiteljska škola u Kopru te Ženska učiteljska škola za ručni rad u Gorici. Program na učiteljskim školama bio je zahtjevan i za upis je bila potrebna stanovita naobrazba, koje nije bilo svuda jer nije ni bilo potrebitih škola.

Srednje škole bile su veoma rijetke, a hrvatske srednje škole na području Istre nije ni bilo. Postojala je samo talijanska gimnazija u Kopru i niža njemačka gimnazija u Pazinu. Pazinska je gimnazija sve do ukidanja 1886. bila njemačka, a već 1873. je bila proširena na osam razreda. Od školske godine 1877./1878., kada je imala 121 učenika, broj je stalno opadao, uz vrlo nizak broj učenika koji su polagali ispit zrelosti. Već je tada u Pazinu postojala pripravnica za učenike koji nisu poznavali njemački jezik. Gimnazija u Kopru je već 1860. uvela talijanski jezik kao nastavni za sve predmete, njemački jezik kao obvezatan 1873., dok se hrvatski jezik mogao učiti kao slobodni jezik. Od 1855. u Piranu je postojala niža realna gimnazija da bi od 1871. dobila status više realne gimnazije, ali od 1883. se postupno ukida zbog maloga broja učenika. U Rijeci od 1849. hrvatski jezik predaje Fran Kurelac, od 1868. djeluje hrvatska gimnazija u Senju, dok je 1890. austrijska vlada u Puli osnovala višu njemačku gimnaziju. Osim gimnazije, od školske godine 1862./1863. djelovala je i talijanska nautička škola u Malom Lošinju, a 1882. ustanovljena je u Poreču dvogodišnja poljoprivredna škola. ${ }^{27}$ Do 1890. stanje u srednjim školama se gotovo nije mijenjalo na području Istre, ali pozitivnih je trenutaka bilo onda kada su otvarane škole poput Delavske škole u Kastvu 1883., nešto poslije Obrtne škole u Puli, državne strukovne škole u Kastvu 1913. i hrvatske poljodjelske škole u Pazinu 1905. ${ }^{28}$

Budući da je odaziv u učiteljske škole bio malen, organizirane su specijalne škole, koje su imale jedinu zadaću da spremaju kadrove za učiteljsku 
školu. Da bi se netko upisao u učiteljsku školu, morao je završiti pripravnicu i položiti prijemni ispit. ${ }^{29}$ Pripravnica za učiteljsku školu otvorena je u Kastvu 20. studenoga 1874. „svetom misom i gruvanjem mužara. Prve godine u pripravničku mušku učionu upisalo se 19 gojenaca." ${ }^{30}$ Ravnatelj pripravnice bio je svećenik Ernest Jelušić, a za učitelje su postavljeni Mate Mogorović, Josip Vlah, Miroslav Grosmann i vjeroučitelj Robert Jelušić, ali je on tijekom školske godine umro pa je na njegovo mjesto imenovan kapelan Ante Šćitar. Prema izvještaju poslanom Pokrajinskom školskom vijeću u Trstu, „učiona“ je svršila s radom 11. listopada 1875. misom zadušnicom. Učenici su za upise doznavali ili preko oglasa koji je objavljivan u lokalnom listu Primorac ili dopisom koji je upravitelj slao okolnim općinama. U dopisu se navode uvjeti upisa, tj. „da se primaju oni učenici koji su ove godine navršili 14 godina ili će navršiti istu u kalendarskoj godini, da imaju čitavo tijelo i ćudoredno neprikosnoveno ponašanje, te da su sa dobrim uspjehom završili pučku ili građansku školu.“ Oni koji se upišu trebali bi dobiti državnu potporu od 50 kruna ako budu dobro napredovali. Ravnatelj pripravnice također sugerira općinskim glavarima „da nagovore roditelje kojeg dobrog djeteta da ga pošalju na tečaj jer za talijanske i slovenske škole ima dosta učitelja, ali za hrvatski jezik nema, pa se valja skrbiti za obrazovanje hrvatskih učitelja.“. ${ }^{31}$ Od 1879. u pripravnicu se primaju i djevojčice. ${ }^{32}$ Učenici koji nisu imali 14 godina također su se mogli upisati u pripravnicu, a dobivali su status izvanrednih slušača i nisu imali pravo na državnu potporu. Ako je netko bio siromašan (što se dokazivalo svjedodžbom o siromaštvu) i nije zbog dobi mogao dobiti državnu potporu, ravnatelj je u pojedinim slučajevima za poneke đake koji dobro napreduju tražio potporu od Bratovštine hrvatskih ljudi u Istri. ${ }^{33}$ Učenici koji su dobivali državnu potporu potpisivali su reverse da će barem šest godina službovati u javnim pučkim školama. Ako prije toga iz bilo kojih razloga napuste službu, obvezuju se da će vratiti svu dobivenu potporu.

Predmeti koji su se učili u pripravnici bili su: vjeronauk (2 sata na tjedan), učevni jezik (hrvatski jezik, 2 sata na tjedan), njemački jezik (5 sati

29 Arhiva Prve riječke hrvatske gimnazije (dalje: APRHG), kutija bez broja, fascikl 1874., spis 26.

30 Isto, pismo br. 4.

31 Isto, spis br. 4.

32 APRHG, kutija bez broja, fascikl 1879., dopis br. 9.

33 APRHG, kutija bez broja, fascikl 1883/4, godišnje izvješće C. kr. Pripravnice za učilište u Kastvu, školska godina 1883/4, sastavili Miroslav Grosmann za bogoštovlje, pjevanje i guslanje i Josip Vlah za ostalo, poslano Zemaljskom školskom vijeću za Istru, bez broja. 
na tjedan), zemljopis i povijest (2 sata na tjedan), računarstvo (3 sata na tjedan), mjerstveno oblikovanje i prostoručno risanje (3 sata na tjedan), prirodoznanstvo (3 sata na tjedan), krasopis (2 sata na tjedan), pjevanje (2 sata na tjedan), guslanje (2 sata na tjedan) i tjelovježba (1 sat na tjedan).

Sačuvano je godišnje izvješće iz 1884. poslano Pokrajinskom školskom vijeću u Trstu, u kojem se iznose glavni problemi učitelja u podučavanju. To su bili slabo predznanje učenika i nesrazmjer intelektualnoga razvoja. Navodi se da učenici imaju od 14 do 19 godina, a da njihovo predznanje odgovara djeci od osam do deset godina, ako su počeli ići u školu od šest godina. ${ }^{34}$ Naročito je teško bilo podučavati hrvatski jezik jer je bilo djece koja nikada u školi nisu učila hrvatski jezik. Prema postojećem Statutu o organizaciji učiteljištva trebalo je veliku pažnju posvetiti učenju njemačkoga jezika (jer je u Kopru nastava većinom bila na njemačkom jeziku), ali to je bilo prerano zbog manjkavosti u poznavanju materinskoga jezika. Poseban problem bilo je računarstvo jer bilo je učenika koji nikada nisu čuli za množenje, a neki nisu znali ni napisati složeni broj npr. 10 080. ${ }^{35}$ Veći broj učenika koji su završavali pripravnicu u Kastvu nastavljao je školovanje na učiteljskoj školi u Kopru. ${ }^{36}$ Od ukupno 71 svršenoga učiteljskog kandidata u razdoblju do 1900. došlo ih je iz kastavske pripravnice 54. Prema tome je pripravnica dala 79 \% hrvatskih učitelja koji su završili u Kopru. ${ }^{37}$

\section{Otvaranje učiteljske škole u Kastvu}

Nakon premještanja učiteljske škole iz Rovinja u Kopar 1872., vlada je već 1873. zbog nedostatka učitelja raspisala ispit na kojem je bilo dovoljno poznavanje abecede. Na taj se ispit prijavio velik broj ljudi raznih struka te su položivši ispit zauzeli učiteljska mjesta. Od kraja 1873. koparska učiteljska škola počela je jačati i povećavati broj polaznika pa se od 1875. vode čak tri odsjeka s njemačkim i talijanskim, slovenskim te „ilirskim“ nastavnim

$34 \mathrm{Na}$ ist. $\mathrm{mj}$.

$35 \mathrm{Na}$ ist. mj.

36 Spisi Pripravnice sačuvani su samo za razdoblje između 1875. i 1888. Manon Giron, „90 godina od preseljenja Učiteljske škole u Kastav“, 44, navodi da je Pripravnica djelovala u kontinuitetu, ali o tome nema dokumenata u APRHG. No, u rubrici „predhodna naobrazba“ iz školskoga imenika 1906./1907. svim kandidatima osim dvojice piše da su završili Pripravnicu u Kastvu. Luka Tidić, „Problematika hrvatskoga školstva u Istri na stranicama Naše sloge (1870. - 1880.)“, 156, prenosi odluku Istarskoga sabora da zatvori Pripravnicu u Kastvu 1877. zbog premalenoga broja polaznika i otvori je u Vrbniku. U APRHG-u postoje spisi iz 1877. i 1878. koji se uglavnom odnose na opremanje učionice u Vrbniku, izdavanje potvrda pojedinim polaznicima da su pohađali Pripravnicu u Kastvu, prijepisi svjedodžbi i sl. Kazimir Jelušić je 8. X. 1880. potpisao dopis da je Visoko šk. Ministarstvo odlučilo ponovo otvoriti pripravnički tečaj za učiteljstvo. APRHG, kutija bez broja, fascikl 1877. i 1878 .

3750 godina rada Učiteljske škole, 34. 
jezikom. Do 1909. škola je uspjela obrazovati 426 učitelja koji su uvelike bili nositelji slovenskoga nacionalnog pokreta. Ženskih učiteljskih škola tih godina nije bilo u Istri, nego tek u Gorici i Dubrovniku. Vrlo je malo hrvatskih učenica polazilo te škole zbog velike udaljenosti ili zbog nemogućnosti školovanja na hrvatskom jeziku. U 1870-ima je bilo pokušaja otvaranja učiteljskih pripravnica u Kastvu, Vrbniku i Dolini, no zbog maloga broja polaznika, sve su zatvorene. ${ }^{38}$

U razvoju slovenskoga i hrvatskoga školstva u Istri veliku su ulogu imale Družbe sv. Ćirila i Metoda osnovane 1886. u Ljubljani, odnosno 1893. u Opatiji. Slovenska organizacija Družbe sv. Ćirila i Metoda od samoga je početka imala 25 podružnica s glavnom zadaćom skrbljenja o slovenskim školama na rubovima slovenskoga etničkog područja, gdje je talijanski i njemački pritisak bio vrlo jak. Nije imala posebnoga razumijevanja za probleme školstva istarskih Slovenaca jer bi to iziskivalo velike troškove pa se nije mogla prihvatiti rješavanja tih problema. Stoga je njezinu ulogu preuzela hrvatska Družba sv. Ćirila i Metoda osnovana u Opatiji (s jakom podružnicom u Trstu), koja je osnivala škole i u predjelima gdje su Slovenci dominirali. U slovenskom dijelu Istre primijećeno je ispreplitanje djelovanja ovih dviju organizacija jer su obje imale svoje podružnice na ovom području. Kako njihovo djelovanje nije bilo uvijek lagano dokazuje i pokušaj ujedinjenja, ali vodstvo slovenske Družbe sv. Ćirila i Metoda je to procijenilo više štetnim nego korisnim pa je došlo jedino do bliske suradnje u pograničnom području. Ovu neujedinjenost dviju srodnih ustanova istarskih Hrvata i Slovenaca na najbolji su način iskoristili talijanski nacionalisti. ${ }^{39}$

Početkom XX. stoljeća sazrijevali su uvjeti da Hrvati Istre dobiju učiteljsku školu na hrvatskom jeziku. Družba sv. Ćirila i Metoda za Istru uspjela je otvoriti mnoge hrvatske škole, a veliku ulogu u tom nastojanju imao je i hrvatski tisak. Sve veći broj novootvorenih hrvatskih škola trebao je sve veći broj učitelja. Hrvatski zastupnici su na Istarskom saboru 20.

38 Milanović, Hrvatski narodni preporod, I, 296-297; Marušič, „Slovenska šola v Istri“, 184.

39 Družba sv. Ćirila i Metoda, osnovana kao udruga za razvitak hrvatskoga i slovenskoga školstva u Istri „na narodno-kršćanskom temelju“, utemeljena 24. veljače 1893., kada je C. i kr. namjesništvo odobrilo njezina pravila. Da bi se povećao broj državnih pučkih škola na hrvatskom i slovenskom jeziku, stvorena je, po uzoru na slične češke i slovenske primjere, privatna udruga koja je osnivala svoje škole i brinula se o njihovoj kadrovskoj i materijalnoj opremljenosti. Nakon utemeljenja udruga je viđenijim osobama iz kulturnoga i političkoga života u Istri i Hrvatskoj poslala okružnicu s programom djelovanja pa su na njezinu adresu stizali novčani prilozi. Na prvoj godišnjoj skupštini 1894. za predsjednika je izabran Dinko Vitezić, koji je na toj dužnosti ostao do 1901. Marušič, „Slovenska šola v Istri“, 184-185; Stipan Trogrlić, „Družba sv. Ćirila i Metoda za Istru“, Istarska enciklopedija, 190-191. 
srpnja 1902. tražili podjelu učiteljske škole u Kopru na hrvatsku, slovensku i talijansku školu. „Sabor je tom prilikom donio čak i zaključak da ne će ni pare votirati za nove pučke škole sve dotle dok se podijeli koparska učiteljska škola. Ovog se zaključka Istarski sabor držao čak i naredne dvije godine. Na sjednici Sabora od 14. listopada 1904. godine prihvaćena je čak i rezolucija školske komisije, u kojoj se kaže: »Poziva se c. kr. vlada, da Saboru saopći prije rasprave o preventivu pokrajinskog školskog fonda, kada li će izvršiti svoje obećanje glede razdiobe učiteljišta u Kopru«. Na ova nastojanja, dat je Istarskom saboru brz odgovor. Na sjednici od 9. studenog 1904. godine c. kr. namjesnik Konrad knez Hohenlohe-Schillingsfürst saopćio je da vlada smatra reformu učiteljišta već kao gotovu stvar, što međutim nije izvršeno, ne toliko zbog velikih troškova jednog u tri učiteljišta, nego što je teško naći prikladna mjesta za rad tih triju škola." ${ }^{40}$

U međuvremenu, u Kastvu na sjednici Općinskoga zastupstva od 16. travnja 1903. predsjednik Franjo Saver Munić obavještava zastupnike da je na upit odaslan c. i kr. vladi od 2. listopada 1902. dobio odgovor da je dovoljno snositi 1/4 troškova za gradnju učiteljišta u Kastvu, u slučaju ako bi se takvo tamo ustrojilo. Frane Dukić također iznosi da je iz pouzdanih izvora saznao da je Ministarstvo za bogoštovlje i nastavu odlučilo da će se učiteljište u Kopru odijeliti tako da se podučavanje nastavi zasebno za Hrvate, Slovence i Talijane. Uslijed toga općinski odbor koji se sastojao od predsjednika Franje Savera Munića i zastupnika Frane Dukića uputio se u Trst; ondje su se 16. ožujka predstavili Alfredu pl. Manussiju de Montesole i zamolili ga da zagovara da općina Kastav dobije učiteljsku školu. On ih je savjetovao da se dogovore s općinskim zastupnicima gdje će smjestiti tu školu jer bi to sigurno pomoglo kod zagovora. ${ }^{41}$ Očito su se zastupnici dogovorili da je najprikladnije mjesto za školu Narodni dom jer je 25 . rujna 1905. u inspekciju došao c. i kr. školski nadzornik Frane Matejčić i konstatirao da zgrada Narodnoga doma nije pogodna za trajno smještanje učiteljske škole, već jedino privremeno, na nekoliko godina. U unutrašnjosti zgrade trebalo je napraviti neke preinake, ali sa zdravstvenoga gledišta zgrada je dobila dozvolu za uporabu. Prema Školskom zakonu iz 1888., uza svaku učiteljsku školu morala je biti opća pučka škola i školska radionica za praktičnu vježbu budućih učitelja i učiteljica pučkih škola. „Osim toga mora uza svaku

4050 godina rada Učiteljske škole, 45.

41 HR-DAR, JU-37-176, zapisnik sa sjednice Općinskoga zastupstva 16. IV. 1903. 
učiteljsku školu za praktičku vježbu u gospodarstvu dotično kućanstvu biti dovoljno prostran vrt i gombalište. ${ }^{\text {“4.2 }}$

Napokon se 1906. općina Kastav počela spremati za preseljenje Muške učiteljske škole. Osiguravanje prostora za učiteljsku školu koja odgovara zakonskim propisima pokazalo se „velikim zalogajem“ za općinu Kastav.

Razmatrana su dva prijedloga: da se proširi zgrada Narodnoga doma s obje strane ili da se sagradi nova zgrada. Nakon dugotrajne i žučne rasprave odlučeno je da se privremeno, na jednu ili dvije godine, učiteljska škola smjesti u Narodnom domu. Dvije učionice općina se obvezala preurediti i pobrinuti se za stan ravnatelja. Odustaje se od kupnje i preuređenja Narodnoga doma jer bi to bilo preskupo, a takva zgrada ne bi sasvim odgovarala zahtjevima koje propisuje Školski zakon jer bi se trebalo posebno pobrinuti za stan ravnatelja i poslužnika, za vježbaonicu i dvoranu za tjelovježbu. Odlučeno je da se sagradi nova zgrada u blizini Narodnoga doma te da općina besplatno ustupi zemljište za pokušalište i školski vrt. Općina se obvezala da će sudjelovati u gradnji nove zgrade s četvrtinom troškova ili da će snositi cjelokupan trošak gradnje uz uvjet da učiteljska škola bude u Kastvu barem 30 godina i da se vlada obveže plaćati primjerenu najamninu. ${ }^{43}$

5. studenoga 1906. stiglo je u općinu Kastav priopćenje Ministra za bogoštovlje i nastavu da je dopušteno preseljenje prvoga razreda hrvatskoga učiteljišta iz Kopra u Kastav. Na sjednici Općinskoga zastupstva 13. listopada zastupnici se ograđuju i obvezuju da će osigurati dogodine prostorije za prijam i drugoga razreda, ali da nisu u mogućnosti primiti cijelu školu. Iz općinske blagajne plaćat će se najamnina za Narodni dom i općina će se pobrinuti za namještaj, rasvjetu, grijanje i zapošljavanje podvornika o svom trošku. ${ }^{44}$

Konačno su 28. studenoga 1906. na kolodvor u Matulje, u pratnji profesora Jakova Jakca, stigli đaci prvoga tečaja kastavske hrvatske učiteljske škole. Učenike je dočekao sam općinski glavar Antun Dukić i ravnatelj Fran Franković. Nastava je započela, kako je tada bilo školskim zakonom propisano, svetom misom. Na misu su pozvani svi općinski činovnici, učiteljsko osoblje i školska mladež mjesnih pučkih škola. Dukić se ispričavao što otvaranje nije bilo svečanije, ali je općina bila u žalosti zbog smrti počasnoga

42 Školski zakon od 31. listopada 1888. s provedbenim naredbama i načelnim rješidbama, pribrao i uredio Antun Cuvaj, Zagreb 1901., 402.

43 HR-DAR, JU-37-178, zapisnik sjednice Općinskoga zastupstva grada Kastva 9. IV. 1906.

44 Isto, zapisnik sjednice 13. X. 1906. 
građanina monsinjora Vinka Zamlića. „Općinsko zastupstvo primilo je ovo priopćenje gospodina predsjednika s veseljem do znanja, jer se ispunila vruća želja cijele Kastavštine, a osobito grada Kastva, te želi toli učiteljištvu zavoda, toli đakom najbolji uspjeh. ${ }^{45}$ Koliko je škola značila za Kastav govori i podatak da su svi koji su pomogli da škola dođe u Kastav imenovani počasnim građanima Kastva. To su bili: knez Konrad Hohenlohe-Schillingsfürst, carski namjesnik, profesor Fran Matejčić, zemaljski školski namjesnik u Trstu, Fran Franković, ravnatelj C. i kr. muške učiteljske škole u Kastvu, te dr. Alfred pl. Manussi de Montesole, ravnatelj državnoga redarstva u Trstu i vladin savjetnik, bivši ravnatelj kotarskoga poglavarstva u Voloskom.

Zanimljiv je bio i izbor podvornika za učiteljsku školu. Na natječaj su se prijavila tri kandidata. Od njih je izabran Ivan Brozović, koji je do tada radio kao općinski redar. ${ }^{46}$ Međutim, zahvaljujući na ukazanoj časti izjavio je da odustaje od posla jer su ga na prijavu za to mjesto prisilili njegovi roditelji. Općina se tada našla u škripcu pa je posao ponudila drugom kandidatu, Lavu Jelušiću, koji je pristao na posao uz godišnju naknadu od 50 kruna i stan u naravi. ${ }^{47}$

Sredinom 1907. gradnja nove školske zgrade još nije bila započela pa općinari predlažu „da se zgrada petoga razreda pučke škole digne na jednokatnicu“, kako bi mogli biti preseljeni treći i četvrti razred iz Kopra. U otpisu Ministarstva za bogoštovlje i nastavu stoji da ako općina ne uspije osigurati novu zgradu do početka školske godine 1909./1910., treći i četvrti razred ostaju privremeno u Kopru. Također stoji da će se iz državne blagajne nadoknaditi troškovi općini razmjerno njezinom doprinosu za zgradu, a u slučaju da se učilište iz Kastva ukine ili prenese, općina će imati prednost pri kupnji zavodske zgrade. Općina je dužna predati besplatno i bez hipotekarnoga opterećenja za novu zgradu zavoda potrebno građevinsko zemljište, s primjerenim komadom zemljišta za školski vrt i za poljoprivredno pokušalište. Imenovano je i povjerenstvo koje je trebalo odrediti najpovoljnije mjesto za novu zavodsku zgradu. ${ }^{48}$ Zaključilo je da je mjesto ispod Fortice jedino prikladno za gradnju nove zgrade jer je u neposrednoj blizini grada te bi i učiteljima i đacima pristup iz stanova i škole do crkve bio pogodan. Budući da je Fortica iznad tadašnjega grada Kastva, općina se

\footnotetext{
45 Isto, zapisnik sjednice 28. XII. 1906.

$46 \mathrm{Na}$ ist. $\mathrm{mj}$.

47 Isto, zapisnik sjednice 23. II. 1906.

48 Isto, zapisnik sjednice 25. IV. 1907.
} 
obvezuje da će sagraditi i pristupnu cestu. To je povećavalo troškove gradnje, ali općina je bila spremna povećati troškove za 1/4 ukupnih troškova. Budući da se te 1907. premješta drugi tečaj iz Kopra, predviđalo se da će biti više učenika koji zbog siromaštva i udaljenosti neće moći kod privatnih kuća plaćati objed pa se predlaže osnivanje đačke kuhinje. ${ }^{49}$

Za gradnju zavoda, pokušališta i vrta trebalo je 3000 do $4000 \mathrm{~m}^{2}$. Općina nije htjela kupovati zemljište prije nego stigne potvrda za lokaciju na Fortici od Ministarstva financija, a ona je stigla tek u svibnju 1908. Ujesen su pozvani svi vlasnici zemljišta koje je bilo predviđeno za novu zavodsku zgradu i s njima su potpisani kupoprodajni ugovori. Zemljište se kupovalo za 1,20 kruna po $\mathrm{m}^{2}$. Jedino je Viktorija Schitter tražila za svoju zemlju daleko više novca (tj. 3 krune za m²), zbog čega je odlučeno da će se zgrada graditi malo niže nego što je bilo predviđeno. ${ }^{50}$ Izgradnja nove zgrade dobrano je kasnila, a to je povećavalo općinske troškove jer se dodatno moralo plaćati najam Narodnoga doma, stan za učitelje i ravnatelja, najam školskoga vrta i prostore za pokušalište, zatim za ogrjev i rasvjetu pa na sjednici od 25. studenoga 1909. zastupnici odlučuju „da se pošalje spomenica na Ministarstvo bogoštovlja i nastave, javnih radova i financija u kojoj se osobito ističe da je općina Kastav za učiteljsku školu već mnogo žrtvovala, daleko više nego li se svojedobno obvezala, i da već neće preko godine 1910. ništa dati, te kako je nužno za tu novu zgradu, koja neka se bezodložno sagradi. ${ }^{\text {"51 }}$

Nisu svi bili za to da se nova učiteljska škola otvori u Kastvu. Većina prosvjetnih radnika u Istri nije bila za Kastav. Učiteljsko društvo Narodna prosvjeta u Pazinu donijelo je čak i rezoluciju, u kojoj se poziva vladu da se ta škola smjesti u Pazinu ili u nekom drugom mjestu. Protiv te odluke bili su i Ferijalni savez Istre i sami učenici. Učenici su čak prijetili i da će pribjeći krajnjim sredstvima ako škola ostane u Kastvu. Učenike je pokušao razuvjeriti osobno i Matko Laginja, ali bez uspjeha. ${ }^{52}$

Kampanja protiv gradnje zgrade učiteljske škole u Kastvu očito se pojačala 1911. Na sjednici od 13. srpnja poglavar Kazimir Jelušić podnosi izvještaj sa sastanka Narodnoga vijeća koje je održano u Pazinu 9. srpnja. Tražilo se premještanje učiteljske škole iz Kastva u neko mjesto s boljim uvjetima, a da se u Kastvu ustroji obrtnička škola zidarskoga smjera. Većina

\footnotetext{
49 Isto, zapisnik sjednice 6. VIII. 1907.

50 Isto, zapisnik sjednice 24. IX. 1908.

51 HR-DAR, JU-37-179, zapisnik sjednice 25. XI. 1909

5250 godina rada Učiteljske škole, 47.
} 
zastupnika glasovala je za taj prijedlog, ali nisu odlučili gdje da smjeste učiteljsku školu. Jelušić je bio ogorčen jer se tražilo od Kastva da odustane od škole nakon što je općina otkupila zemljište i gotovo sklopila ugovor s vladom. Ističe da je kampanja protiv Kastva počela prije tri, četiri mjeseca po novinama. Kaže da se u listu Narodna prosvjeta, u broju 6, iznose neistine, gadarije, klevete i laži protiv Kastva: da se u Kastavu kune i pijančuje, da se ne mogu nadzirati đaci kada vide sve te loše primjere, da je mjesto dosadno, da je hrana loša, stanovi skupi, da su sobe nad svinjcima, da se ne mogu dobiti poljoprivredni proizvodi ni meso jer se u Kastvu ne kolje, da nema pošte, već da se pošta donosi iz Matulja, da se ne mogu kupiti biljezi, da u Kastvu nema inteligencije i dr. Te je optužbe pobijao Vjekoslav Spinčić, ali su ga zastupnici stalno prekidali. Što se stanova tiče, svi učenici imaju stan osim sedmorice koji zbog troškova stanuju u okolici kod roditelja. Bilo je još desetak stanova koji se mogu iznajmiti kada bi se imalo komu. Jelušić ističe da su prigovori protiv Kastva prigovori koji bi se mogli uputiti i protiv svih ostalih gradova u Istri. Zaključak ove sjednice bio je da se, iako je stanovništvo Kastavštine oklevetano i omraženo kao nikada prije, narod drži čim mirnijim, a općina da ne donosi nikakvih odluka, već da se sklapanje pogodbe prepusti svome tijeku. ${ }^{53}$

Na tom saboru kao moguće lokacije za gradnju škole predlagani su Pula, Pazin i Opatija. Na koncu je kao jedini prijedlog za novu školu ostala Opatija, koja je tada već bila poznato svjetsko kupalište i bila najmanje podesna za školu, nakon čega su i delegati iz središnje Istre, koji su zagovarali Pulu ili Pazin, prihvatili stajalište da je najbolje da škola i dalje ostane u Kastvu. ${ }^{54}$

Pogodba o gradnji škole između općine i Ministarstva za bogoštovlje i nastavu napokon je sklopljena 3. kolovoza 1911. Na carski erar uknjiženo je zemljište predviđeno za gradilište škole i ceste te doprinos općine od 30 ooo kruna. ${ }^{55}$

\section{Nastava na učiteljskoj školi}

Početne 1906. iz Kopra u Kastav došlo je dvanaest učenika. Bili su to Anton Barbarić iz Dobrinja, Jakub Brdar iz Pazinskih Novaka, Petar Facchini

\footnotetext{
53 HR-DAR, JU-37-180, zapisnik sjednice 13. VII. 1911.

5450 godina rada Učiteljske škole, 47.

55 HR-DAR, JU-37-180, zapisnik sjednice 22. IX. 1911. Zapisnici sjednica Kastavskoga poglavarstva nakon 1911. nisu preuzeti u DAR-u. Na zgradi u kojoj se nalazila škola piše da je sagrađena 1912., ali o tome nema zapisa niti u DAR-u, niti u APRHG-u.
} 
iz Pazina, Viktor Grbac iz Srdoča, Josef Poropat iz Lanišća, Josef Sušanj iz Brnasi, Antun Šebalja iz Malinske, Vincent Šepić iz Voloskoga, Antun Ujčić iz Staroga Pazina, Fran Ujčić iz Jurdani, Johann Vivoda iz Sovinjskoga Polja i Johann Zlatić iz Potpićna. ${ }^{56}$ Nastava se održavala svakoga dana ujutro i popodne od ponedjeljka do subote, osim četvrtkom. Četvrtkom su se učenici imali pripremati. Iz toga razdoblja sačuvane su samo razredne i matične knjige, ali ne i zapisnici sa sjednica. Nastavu su 1908. pohađala sva četiri tečaja, a škola je brojila 67 učenika. U I. tečaju bilo je 24 učenika, u II. 18, u III. 14, a u IV. 10 učenika. ${ }^{57}$

Te su godine u prosincu održani prvi ispiti zrelosti. Ispit zrelosti polagao se iz svih predmeta, pismeno i usmeno, osim iz risanja, pjevanja, tjelovježbe i vjeronauka. Iz tih predmeta nije bilo pismenoga ispita. Ispiti su se održavali pred povjerenstvom koje su činili nastavnici i vladin povjerenik. Na prvom ispitu zrelosti u prosincu 1908. bila su samo tri učenika, ali već na idućem ispitu bilo je 12 kandidata, od čega su šest bile djevojke. Iako je škola bila muška, ispite zrelosti mogle su polagati i djevojke. ${ }^{58}$

Ustroj učiteljske škole, predmeti, obuka, državne potpore i pravila ponašanja bili su propisani Školskim zakonom. ${ }^{59}$ Zadaća je učiteljske škole bila da se učenici teoretski i praktično obrazuju za učiteljsku službu u pučkim školama. Pravila ponašanja bila su stroga i budno se pazilo na ćudoređe polaznika učiteljske škole jer se smatralo da oni moraju biti uzor svim ostalim mještanima. Pa tako npr.: „učiteljski pripravnici dužni su sve učitelje učiteljske škole i vježbaonice svagda štovati, slušati i prema njima iskreni biti. Povreda dužnog štovanja, uskrata poslušnosti i izvraćanje istine kazniti će se.“ Učenici su smjeli stanovati samo kod čestitih obitelji, a prisvajanje tuđih, pa i najneznatnijih stvari, kažnjavalo se vrlo strogo, čak i isključenjem iz škole. Učiteljski pripravnici morali su se i izvan škole ponašati pristojno i uljudno. Učenicima je bilo strogo zabranjeno hodanje ulicom kasno navečer te posjećivanje gostionica, kavana i plesova. A i za pijančevanje, nepristojno ponašanje, svađe i druge izgrede mogli su biti kažnjeni isključenjem iz škole. Pušenje duhana bilo je u potpunosti zabranjeno učiteljskim pripravnicima I. i II. tečaja, a onima III. i IV. tečaja samo na javnim mjestima. ${ }^{60}$

56 APRHG, Glavni katalog šk. godine 1905/6-1907/8, arhivski br. P78.

$57 \mathrm{Na}$ ist. mj.

58 APRHG, Katalog ispita osposobljenja od god. 1908. - 1918. - koncepti svjedodžba osposobljenja, arh. br. P82.

59 M. Giron, „90 godina od preseljenja Učiteljske škole u Kastav“, 392-397.

60 Isto, 393, 395-397. 
Zanimljivi su razlozi kažnjavanja učenika. Tako je npr. Nikola Zec, učenik III. tečaja, školske godine 1908./1909. kažnjen jer je jednom došao u školu, a da nije ni pogledao lekcije iz pravopisa. Ivan Debeljuh i Franjo Demajzes kažnjeni su jer su pohađali ples. Učenici II. tečaja Dragutin Gabrielić kažnjen je jer je svirao u nedopušteno vrijeme, a Benedikt Badurina jer je brbljao za vrijeme obuke, smijao se na gimnastici i skakao po školi. ${ }^{61}$

U vrijeme Prvoga svjetskog rata nastava se nastavila održavati uz brojne teškoće. Glad je bila sveprisutna pa dva učenika I. tečaja školske godine 1916./1917. odustaju od školovanja zbog nedostatka hrane. Većina učenika i nastavnika je mobilizirana. Tako je školske godine 1916./1917. u školu bilo upisano 34 učenika, od kojih je 19 bilo unovačeno. U III. i IV. tečaju ostao je samo po jedan učenik. ${ }^{62}$

\section{Djelovanje škole između dva svjetska rata}

Krajem rata Istru i Kastav je okupirala vojska Kraljevine Italije unatoč pokušajima da se na spomenutom teritoriju uspostavi Država SHS. Stanovništvo Istre se uvelike zainteresiralo za novu južnoslavensku državu i o njoj se s oduševljenjem pričalo. Međutim, ovo je oduševljenje trajalo svega nekoliko dana jer je talijanska vojska vrlo brzo ušla na teritorij Istre. Početkom studenoga 1918. Kraljevina Italija je dobila dopuštenje da okupira na istočnoj obali Jadrana cijeli teritorij do crte određene Londonskim ugovorom. Okupacija Istre je protekla u vrlo složenom i napetom političkom stanju, ali i teškoj gospodarskoj krizi. Početna zbunjenost i ogorčenost hrvatskoga i slovenskoga stanovništva vrlo je brzo prešla u otpor; kako na selu, tako i u gradovima te većim središtima izbijali su sukobi jer su Talijani započeli uvoditi svoju upravnu organizaciju. ${ }^{63}$

Za talijanske okupacije Istra je vrlo brzo dobila novu političko-teritorijalnu organizaciju jer je središte pokrajinske vlasti bilo smješteno u Poreču, dok je za sjedište gubernija bio određen Trst kao upravno i gospodarsko središte cijele Julijske Venecije. Istra je bila podijeljena na šest političkih kotara koji su se gotovo poklapali s područjima kotarskih kapetanata iz vremena Austro-Ugarske, sa sjedištima u Puli, Poreču, Pazinu, Kopru, Volo-

\footnotetext{
61 APRHG, Glavni katalog školskih godina 1905./1906., 1906./1907. i 1907./1908., arh. br. P78.

62 APRHG, Zapisnici sa sjednica Učiteljskoga zbora Državne učiteljske škole u Kastvu od IX. 1921. do 24. VIII. 1936., arh. br. 98, zapisnik od 27. V. 1929.

63 Milanović, Hrvatski narodni preporod, II, 475-481; Darko Dukovski, Istra i Rijeka u prvoj polovici 20. stoljeća (1918-1947) (dalje: Istra i Rijeka), Zagreb 2010., 16-19.
} 
skom/Opatiji i Malom Lošinju. Na području Istre najvišu su vlast obnašali civilni komesari, dok su općine vodili načelnici u suradnji sa Savjetodavnim odborom. Potpisivanjem Rapalskoga ugovora 1920. i Zakonom o aneksiji iz iste godine Istra i pripadajući otoci (Cres, Lošinj, Unije, Susak i niz manjih, nenastanjenih otoka) pripojeni su Kraljevini Italiji. Dekretom iz 1921. Italija je ukinula ratno stanje $u$ anektiranim zemljama, ali decentralizacijske političke tendencije su navele novu vladu da se požuri s izjednačavanjem zakonodavstva. Politička prijelomnica je bila zakonska odredba iz 1922. kojom su utvrđene podjele nadležnosti između prefekta i drugih pokrajinskih vlasti te ministarstva. Ovom su odredbom ukinuti generalni civilni komesarijati ustupivši mjesto prefekturama. Civilni komesari političkih kotara postaju potprefekti okruga. Međutim, ovaj proces izjednačavanja zakonodavstva je dovršen tek 1922., kada na vlast dolaze fašisti i time Istra postaje samo jedna od talijanskih pokrajina. Imala je svoga prefekta, potprefekta, prefekturno vijeće i upravni odbor s glavnim gradom pokrajine i prefekture $u$ Puli. Godine 1924. dolazi do manjih teritorijalnih promjena kada su okrug Volosko/Opatija i još neke istarske općine postale dijelom nove riječke pokrajine. ${ }^{64}$

Već prve poratne godine u Istri se mogla vidjeti masovna politizacija društva u kojoj se prepoznaju tri glavne političke grupacije: (1) lijevo usmjerene, nacionalno i socijalno heterogene snage okupljene oko socijaldemokracije, (2) talijanske i (3) hrvatsko-slovenske građanske nacionalističke snage okupljene oko vodećih ljudi prijeratnoga političkog života. U situaciji brzih preobrazbi i pregrupiranja vidljivi su začeci obnove stranačkoga života u gradskim sredinama zapadne i južne Istre, stoga nastaju političke stranke novih organizacijskih oblika. Glavnina se političke scene formirala 1920., iako su političke stranke nastajale i 1919. i 1921. Osim toga, južna i zapadna Istra postala su područja okupljanja mladih talijanskih vojnika povratnika koji su se uključivali u rad raznih domoljubnih društava iz kojih će kasnije nastati prve fašističke organizacije. Nešto kasnije su se vratili i predratni iredentisti koji su s dolaskom talijanskih nacionalista unijeli neke nove impulse političke borbe čime su stvoreni realni uvjeti koji su fašističkoj i nacionalističkoj ideologiji dali prvotni organizacijski oblik. Tada se počelo govoriti da je talijansko stanovništvo ugroženo od slavenstva i boljševizma, što je stvorilo uvjete za oblikovanje zajedničkoga antihrvatskog i antisocija- 
lističkog bloka talijanskih stranaka u Julijskoj Veneciji. U takvim povijesnopolitičkim okvirima pojavile su se i prve fašističke organizacije. Međutim, ove organizacije nisu ni izbliza podsjećale na fašističke organizacije stvorene početkom 1920-ih godina. Socijalno-nacionalna struktura prvih fašističkih i profašističkih organizacija u Istri specifična je u odnosu na ostale krajeve, posebno zato jer je bila vrlo heterogena. Bitne razlike fašizma u Istri u odnosu na fašizam u ostalim krajevima Italije svode se na patološku slavofobiju, antimonarhizam i antiklerikalizam. ${ }^{65}$

Godine 1924. utemeljena je Riječka prefektura sa sjedištem u Rijeci. Obuhvaćala je liburnijski dio Istre (od Plomina na sjever), dio Kastavštine i susjedno slovensko područje na sjeveru. Pokrajina je bila sastavljena od tri kotara: Rijeka, Volosko-Opatija i Ilirska Bistrica. Fašistička je organizacija u Rijeci osnovana relativno kasno u odnosu na Istru i Slovensko primorje zbog situacije 1918. - 1924. U Rijeci je jezgra fašističke organizacije bila Riječka dobrovoljačka legija Giovannija Host-Venturija od koje je kasnije nastala legija MVSN. I u Rijeci su osnivane fašističke organizacije mladeži. Uspostavljanje korporativnoga sustava u Rijeci teklo je mnogo brže nego u Istri zbog specifične društvene strukture. U samom gradu i pokrajini osnivači fašističke organizacije i stranke zauzeli su najvažnije funkcije, dok se fašističko članstvo podijelilo na brojne frakcije zaokupljene ostvarivanjem vlastitih interesa. Međutim, osobni pečat razvitku i dekadenciji grada i pokrajine davali su Giovanni Host-Venturi i Riccardo Gigante. S druge strane, prefekti Rijeke bili su ljudi izvana koji nisu razumjeli probleme pokrajine niti se posebno trudili popraviti zatečeno stanje. ${ }^{66}$

Riječko je gospodarstvo, poput onoga u Istri, brzo propadalo, pa je, primjerice, pred Drugi svjetski rat lučki promet dostigao tek 23\% prometa ostvarenoga pred Prvi svjetski rat. Središnja fašistička vlast ni na koji način nije pomogla ozdravljenju riječke i pokrajinske privrede. Štoviše, karakteristika dvadesetogodišnje fašističke vladavine su zapuštena postrojenja i skladišta te gradska infrastruktura. ${ }^{67}$

Nakon Prvoga svjetskog rata vladinom je odlukom od 14. studenoga 1919. osnovno školstvo prešlo u ruke općina i pokrajina, što je do kraja realizirano tijekom 1920. U tom je razdoblju veliku ulogu imala Lega naziona-

65 Isto, 21-28. 
le. ${ }^{68}$ Po dolasku talijanske uprave u Istru školske su vlasti počele razmišljati o ukidanju slovenskih i hrvatskih škola. U školama su počeli djelovati učitelji koji su došli iz drugih talijanskih pokrajina, dok su domaći učitelji prebačeni na područje gdje je bilo mješovito stanovništvo. Nakon školske godine 1918./1919. predložena je podjela Julijske Venecije na tri jezična područja: područje s čisto talijanskim stanovništvom, područje mješovitoga stanovništva te područje čisto slovenskoga stanovništva. Hrvatsko i slovensko školstvo proživljavalo je teške trenutke zbog progona učitelja, ali i zbog reforme uslijed koje je bez posla ostalo dvjestotinjak slovenskih i hrvatskih učitelja. Tada je ministar Giovanni Gentile zaprimio poslanike s protestom o diskriminaciji, ali ga je odbacio kao neutemeljen s obrazloženjem da svi državljani Kraljevine Italije moraju znati službeni (talijanski) jezik. Iako je zakon pomagao postupno uvođenje talijanskoga jezika u škole, pokrajinske su vlasti bile te koje su poboljšavale prelazak slovenskih škola na talijanski jezik. ${ }^{69}$

Kraljevina Italija je odmah po dolasku u hrvatski dio Istre zatvorila hrvatsku gimnaziju u Pazinu i privatnu žensku učiteljsku školu u Pazinu. Od kraja rata do potpisivanja Rapalskoga ugovora Kastav se nalazio pod talijanskom okupacijom. U cijeloj Istri zatvorene su sve hrvatske škole, ali je učiteljska škola u Kastavu nastavila s radom. Za ravnatelja je postavljen Edoardo Cubelli iz Zadra. U Kastvu su započeli progoni i uhićivanja inteligencije i svih koji su se protivili talijanskoj okupaciji. Pred Talijanima su pobjegli i neki nastavnici iz učiteljske škole u Kraljevinu SHS, ali nastava se održavala i nadalje, pa je 1919. maturiralo sedam, a 1920. 13 učenika. Ispitima je predsjedao ravnatelj Cubelli. Potpisivanjem Rapalskoga ugovora (12. XI. 1920.) Kastav je pripao Kraljevini SHS. Ravnatelj Cubelli organizirao je maturu znatno prije roka, od 19. do 21. svibnja 1921., tj. pet dana prije ulaska vojske Kraljevine SHS. Nakon mature povukao se u Opatiju i postao ravnateljem Niže gimnazije. Sa sobom je odnio zapisnike s mature, a sve učenike rodom iz područja koje je pripalo Italiji poslao je u Arbanase (koji su također pripali Italiji) kraj Zadra. ${ }^{70}$

68 Lega nazionale je iredentistička talijanska udruga osnovana 1891. u Trentu radi promicanja ljubavi prema talijanskom jeziku i kulturi te otvaranja i organiziranja talijanskih škola u granicama Austro-Ugarske na etnički miješanim prostorima. Naslijedila je udrugu Pro patria osnovanu 1885. u Trentu s podružnicama i u Austrijskom primorju. Aktivisti su bili angažirani u nacionalnoj borbi protiv Hrvata i Slovenaca, a najviši su društveni slojevi bili povezani s talijanskom strankom Società politica istriana. Vanni D'Alessio, „Lega Nazionale“, Istarska enciklopedija, 439; Cukrov, Izmedu obrazovanja i denacionalizacije, 147-155, 197209; Marušič, „Slovenska šola v Istri“, 184-188.

69 Marušič, „Slovenska šola v Istri“, 188-189.

70 Iz tog razdoblja nije sačuvan nijedan školski dokument. 50 godina rada Učiteljske škole, 58. 
Od 1918. u školu se primaju i djevojke. Razloga je zacijelo bilo više. Zbog rata (tj. mobilizacije učenika) i okupacije bio je nedovoljan broj muških učenika, a i zatvorena je privatna ženska učiteljska škola u Pazinu, ${ }^{71}$ pa se učenice nisu imale gdje školovati za učiteljice, osim u Dubrovniku koji je bio daleko. Možemo samo nagađati koji je razlog bio primaran za Učiteljski zbor da odobri primanje i djevojaka u školu. Zakon je dopuštao mješovite škole, ali samo ondje gdje nije bilo moguće organizirati odvojene. Od tada nadalje polovicu đaka činile su učenice.

Iako je Kastav ušao u Kraljevinu SHS, veći je dio nekadašnje Općine Kastav pripao Italiji, koja je na dobivenom području osnovala dvije općine: Matulji i Klana. Pod Italijom su ostale šume u okolici Kastva, obalni pojas od Preluka do Kantride i željeznička pruga Matulji - Rijeka. Tada započinje izuzetno teško ekonomsko razdoblje za Kastav. Općina je izgubila 4/5 svojih šumskih resursa, a gotovi svi Kastavci koji nisu htjeli optirati za Italiju ostali su bez posla u obližnjem industrijskom središtu Rijeci. Kastav se našao i u prometnoj izolaciji jer da bi se došlo do obližnjega Sušaka trebalo je prijeći granicu dva puta. Zamrla je i trgovina jer su prijevozni troškovi višestruko poskupjeli. Transport robe i putnika mogao se obavljati samo preko željezničke postaje Bakar u Škrljevu, a kasnije preko sušačkoga kolodvora. Kraljevina SHS, a poslije Kraljevina Jugoslavija nije pokazivala previše razumijevanja i skrbi za poticanje gospodarskoga razvoja Kastva. Siromaštvu stanovništva nisu išli na ruku ni velika gospodarska kriza ni zaoštravanje odnosa između Italije i Jugoslavije. ${ }^{72}$

Očekivalo se da će vlada nove države pokazati više interesa za ovu pograničnu školu. U školi su se mogli školovati učenici iz Gorskoga kotara i Hrvatskoga primorja, ali to se nije dogodilo. Nova vlada odmah je ukinula pripravnicu u Kastvu pa je nedostajalo učenika koji bi se mogli upisati u školu. Čak je bilo nastojanja da se škola u Kastvu ukine i premjesti na Sušak. Ali tada je ponovno Općina Kastav povela akciju za otvaranjem Više pučke škole. Učitelji su se angažirali i da prikupe učenike sušačkih škola, da ih se privatno poučava i omogući im se da svrše treći i polažu četvrti razred škole, tako da je škola dobila potreban broj učenika za I. razred.

Iako je imala dovoljan broj učenika, sredinom dvadesetih godina ponovno je pokrenuta inicijativa da se škola premjesti u neko drugo mje-

71 Privatna ženska učiteljska škola djelovala je u Pazinu od 1912. do 1918. Isto, 57.

72 A. Giron, „Gospodarske nedaće općine Kastav nakon razgraničenja između Kraljevine SHS i Kraljevine Italije“, 60-61. 
sto. Ali intervenirali su pjesnik Viktor Car Emin, Uliks Štanger (tada jedini zastupnik istarskih Hrvata u rimskom parlamentu) i Julije Miran, bivši pročelnik Općine Volosko, koji su ministru prosvjete u Beograd 30. lipnja 1925. iz Opatije poslali pismo u kojem mole: „da se škola ostavi jer je škola jedino žarište, s kojeg dolazi nešto svjetla u ove naše nesretne krajeve... Đaci koji polaze preparandiju, drže između nas i oslobođenog grada vezu, koja nam je toliko potrebita, naročito u trenutku, gdje tuđinska propaganda i penetracija radi svom silom da uguši svijest, što se među ovim našim narodom tako lijepo ukorijenila. “73 Zbog te intervencije škola je i ovaj put opstala.

U zapisnicima sjednica Učiteljskoga zbora koji su sačuvani nema rasprava o političkim i ekonomskim nedaćama koje su tištile Kastav. Raspravljalo se o potporama siromašnim učenicima, ispitima zrelosti, kaznama i školskim izletima. Da bi netko dobio potporu ili stipendiju morao je biti odlična vladanja, biti posve siromašan, ne plaćati nikakva poreza i svršiti prethodni razred s odličnim ili vrlo dobrim uspjehom te najviše tri dobre ocjene. Potpore je predlagao Učiteljski zbor Ministarstvu bogoštovlja i nastave.

Godine 1927. donesen je novi zakon o školovanju na učiteljskim školama. Po njemu školovanje za učitelje traje pet godina, a da bi netko bio primljen u školu mora apsolvirati nižu srednju ili građansku školu i položiti ispit iz sluha. Na kraju školovanja učenici polažu ispit zrelosti koji se sastoji iz praktičnoga ispita (jedno obučavanje u bilo kojem razredu osnovne škole), pismenoga ispita iz srpsko-hrvatskoga jezika, iz pedagogije i iz matematike, usmenoga ispita iz srpsko-hrvatskoga jezika, iz pedagogije s metodikom, iz narodne povijesti s narodnim zemljopisom i još iz tri predmeta u kojima je đak tijekom školovanja pokazao najslabiji uspjeh.

Pravila ponašanja vrlo su slična zakonu iz 1888. pa je npr. zabilježeno da se učenica II. tečaja Milica Radić usprkos zabrani šetala i po danu i u noćno doba s muškom osobom ${ }^{74}$ a otac Jedvige Jelušić došao se žaliti u školu na Ivana Goluba da bez njegova dopuštenja izlazi s njegovom kćerkom i zatražio da ga izbace iz Kastva, ali je Golub dobio „samo“ ukor. ${ }^{75}$ Česte su kazne i zbog pohađanja gostionica i plesova.

7350 godina rada Učiteljske škole, 61.

74 APRHG, Zapisnici sa sjednica Učiteljskoga zbora Državne učiteljske škole u Kastvu od IX. 1921. do 24. VIII. 1936., arh. br. 98, zapisnik sjednice Nastavničkoga zbora 25. VI. 1927.

75 Isto, zapisnik sjednice Nastavničkoga zbora 5. XI. 1935. 
Godine 1929. opet je donesen novi zakon o učiteljskim školama pa je škola u Kastvu ukinuta jer nije odgovarala propisanim standardima. Ovaj put uspješnu akciju za ponovno otvaranje škole proveo je profesor Vjekoslav Spinčić. Školske godine 1930./1931. nastava je počela tek 4. studenoga zbog nedovoljnoga broja nastavnika i preseljenja u novu zgradu. ${ }^{76} \mathrm{Na}$ sjednici općinskoga zastupstva istaknut je značaj učiteljske škole za nacionalni, državni i gospodarski razvoj cijele Kastavštine. Predloženo je ravnateljstvu škole da zajednički utvrde datum svečane proslave ponovnoga otvaranja jer bi tada održali izvanrednu svečanu sjednicu na kojoj bi se za počasne građane proglasilo one koji su shvatili nacionalnu i državnu važnost škole. To su ministar predsjednik general Petar Živković, ministar prosvjete Božo Maksimović i ban Savske banovine Josip Šilović, a svečano bi se izrekla zahvala Vjekoslavu Spinčiću, kastavskom općinaru i banskom vijećniku za Kastavštinu. Tražilo se i posebno Kraljevo odobrenje da se dopusti da škola u Kastvu nosi ime Učiteljska škola kralja Aleksandra u Kastvu. ${ }^{77}$

Od 1935., nakon vanjskopolitičkoga približavanja Jugoslavije Francuskoj i Velikoj Britaniji, obavezan predmet na ispitu zrelosti uz njemački postaje francuski jezik, a od tada učenici dobivaju kao nagradu za dobar uspjeh knjige na francuskom.

Važan dio školovanja bile su ekskurzije. Putovanja su se organizirala uz državnu pripomoć, a ostatak novca dobavljao se organiziranjem javnih priredbi i zabava. Ovo je primjer iz 1933.: „Cilj ekskurzije je upoznavanje prirodnih krasota i kulturnih tekovina jednog dijela naše domovine, a ekskurzija će trajati 14. V. - 21. V. Dne 14. maja: Kastav-Sušak, iz Sušaka lađom za Šibenik, 15. i 16. maja bavljenje u Šibeniku i izlet na slapove Krke. Učenici će noćiti u Putničkom odjelu. Drugog dana tj. 16. maja polazi se za Plitvička jezera. Noćište: Panzion Labud, 18. maja poslije podne kreće se za Zagreb. Noćište: konačište oblasnog odbora Jadranske straže. 19. maja, u noći, vraćaju se đaci u Kastav kamo stižu 21. maja ujutro. Za ekskurziju prijavili su se svi đaci IV. i V. razreda, pa će prema tome poći na ekskurziju 11 učenika i 16 učenica, ukupno 27. Za izvođenje ove ekskurzije škola raspolaže sa svotom od 2000 dinara. Zaključuje se da se zamoli državna pomoć u

76 Riječ je o zgradi današnje osnovne škole. Zgrada koja je sagrađena 1912. bila je oštećena u ratu i za vrijeme okupacije. Općini je uspjelo osigurati kredit pa je zgrada bila popravljena i uređena, a za nju je nabavljen i novi namještaj. Škola je tada dobila sve uvjete za opstanak prema zakonu o učiteljskim školama, pa čak i internat s posebnim inventarom. Isto, zapisnik sjednice Nastavničkoga zbora 3. XI. 1930.

77 HR-DAR, JU-37-185, spis br. 7352/30 od 7. XI. 1930. 
iznosu od 2000 dinara. Do novaca za ekskurziju došlo bi se organiziranjem javnih priredbi. “" ${ }^{78}$

Ni novo ime nije pomoglo školi da opstane. Od školske godine 1933./1934. ne upisuju se novi prvi razredi pa je iz godine u godinu učenika bilo sve manje. Na posljednjoj sjednici Nastavničkoga zbora zapisano je „da su se nastavnici prijavili na posao ali da nemaju nikakve upute o daljnjoj sudbini škole. Čim dobiju nekakvu naredbu, direktor će javiti svim nastavnicima. Ako budu premješteni na neku drugu školu, direktor će ih pozvati da osobno predaju zbirke i knjižnice, kako bi se mogla provesti propisana likvidacija škole.“79 Ali nikakve daljnje upute nisu stigle i škola prestaje s radom. U razdoblju između dva rata učiteljsku školu u Kastvu završilo je 193 učitelja. $^{80}$

\section{Razdoblje Drugoga svjetskog rata i neposrednoga poraća}

Ulaskom Kraljevine Italije u rat 1940. velik je broj muškaraca mobiliziran u vojne postrojbe. Već naredne 1941., temeljem Rimskih ugovora između Kraljevine Italije i Nezavisne Države Hrvatske, proširena je Kvarnerska pokrajina na kotar Čabar i dijelove kotara Delnice i Sušak te otoke Krk i Rab. Iako pripojeno Kvarnerskoj pokrajini, područje je bilo pod upravom posebnoga ureda Riječke prefekture. Odmah se potom počelo s talijanizacijom ovoga hrvatskog područja i to zatvaranjem hrvatskih škola te zatvaranjem hrvatskih društva. Talijanski je jezik postao službenim jezikom na području na kojem ga je malo tko znao i razumio, a ubrzo se započelo s osnivanjem i režimskih organizacija mladeži i fašističkih udruga u koje je hrvatsko stanovništvo nasilno upisivano. U takvoj je situaciji bilo najteže to što većinsko hrvatsko stanovništvo nije imalo mogućnost prihvatiti hrvatsko državljanstvo i optirati u NDH. Iako je provedena politika javnih radova i gospodarski ustupci, fašističke vlasti nisu uspjele privući novo stanovništvo. Štoviše, nakon pojačanje represije vojske, pljačke i pokušaja etničkoga čišćenja, ojačala je antifašistička fronta koja je do punoga izražaja došla kapitulacijom Italije 1943. Padom fašizma u Riječkoj pokrajini velik je broj riječkih fašista napustio grad i pobjegao u Italiju. Na područje Kastva 1942. došla je nekolicina partizana da bi se osnovala vojna postrojba koja bi bila

78 APRHG, Zapisnici sa sjednica Učiteljskoga zbora Državne učiteljske škole u Kastvu od IX. 1921 . do 24. VIII. 1936., arh. br. 98, zapisnik sjednice Nastavničkoga zbora 23. II. 1933.

79 Isto, zapisnik sjednice Nastavničkoga zbora 24. VIII. 1936.

8050 godina rada Učiteljske škole, 63. 
vezana uz Istru i bila sastavljena od Istrana. Ova je postrojba bila pripojena II. bataljunu Vladimir Gortan, no većina je boraca u postrojbu pristigla krajem 1942. i u prvoj polovici 1943., kada je propast fašističke vladavine bila već izvjesna. U takvoj je situaciji NOP u Istri ušao u novu fazu, iako se na području Kvarnerske pokrajine razvijao u uvjetima koji su se uvelike razlikovali od onih na ostalim dijelovima kvarnerskoga primorja. Situacija se u Kvarnerskoj pokrajini uvelike razlikovala i u odnosu na Istru. Naime, Rijeka je imala brojno radništvo koje organizacijski nije bilo povezano, dok je komunistička organizacija bila razbijena i raspuštena. U tom razdoblju još uvijek nije postojala neka druga politička snaga koja bi radnike povela u antifašističku borbu. Riječani tada još uvijek nisu imali razvijen osjećaj pripadnosti niti jednom susjednom narodu, dok je radništvo samo prihvaćalo značaj antifašističke borbe i program socijalnoga oslobođenja, ali ne i borbu za nacionalno oslobođenje. Iznimka je bilo stanovništvo Kastva i Krasa. Tijekom 1942. mjesni komitet KP Rijeke angažirao se u pripremama za antifašistički otpor, ali sveukupno je NOP sporo napredovao u odnosu na Sušak, Gorski kotar i Kastavštinu gdje se počeo razvijati već 1941. Nakon izbjegavanja otvorenih borbi s neprijateljem, sredinom 1942. nastaju bolje naoružane partizanske formacije poput Sušačko-kastavske čete. U kratkom je razdoblju došlo do potrebe stvaranja većih vojnih postrojbi, nakon čega su se postrojbe s riječkoga područja povezale s onim slovenskim, pa su se u svima njima nalazili i Istrani. ${ }^{81} \mathrm{U}$ završnim godinama Drugoga svjetskog rata na području Rijeke, Kastavštine i Grobinštine nastale su veće vojne postrojbe koje su održavale frontu na području kvarnerskoga primorja, Gorskoga kotara i Like. Tada nije bilo nimalo lako ni jednostavno njima koordinirati, a kamoli izdržati snažne napade njemačke vojske koja je htjela u najmanju ruku neutralizirati ili smanjiti vojno značenje ovih postrojbi. Stoga su od ljeta 1944. pa do tzv. Riječke bitke vojne postrojbe konstantno popunjavanje redovitim novačenjem stanovništva, što u uvjetima preustroja operativnih postrojbi nije bilo nimalo jednostavno. ${ }^{82}$

Za vrijeme Drugoga svjetskog rata Talijani su okupirali i Kastav. Za upravitelja svih kastavskih škola postavljen je Talijan koji je sve škole smjestio u zgradu učiteljske škole. Inventar učiteljske škole zbog toga je nekoliko puta preseljen. Već za prvih dana okupacije došao je iz Opatije fašist Fran- 
cesco Brombini koji je s pripadnicima fašističke mladeži (GIL) opljačkao veći dio kuhinjskoga inventara, krevete, posteljinu, ormare, uništio instalacije, a školsku knjižnicu dali su odvesti u tvornicu papira na Sušaku. Dio knjiga spašen je tako što su neki radnici te knjige odnijeli kući. Ravnateljica građanske škole spasila je školsku knjižnicu tako što je knjige prilikom seljenja donijela u svoj dom, a arhivu učiteljske škole sakrila pod svoj krevet te tako spasila veći dio zapisnika sa sjednica i ispita zrelosti.

Krajem Drugoga svjetskoga rata, čim je to bilo moguće, tj. čim su bila oslobođena neka sela u Kastavštini 1944., krenulo se s organiziranjem učiteljskih tečajeva. Prvi tečaj održan je u selu Klarići od 6. do 21 . ožujka. ${ }^{83}$ Sačuvan je jedan zapisnik o polaganju privatnoga ispita zrelosti u Kastvu iz rujna 1944. za učiteljicu Mariju Polonijo iz Krka, koja je završila privatnu talijansku učiteljsku školu u Rijeci.

Kastav je oslobođen 3. svibnja 1945. Već u kolovozu počeli su popravci na zgradi škole i internata. Radove su izvodili stanovnici okolnih sela. Škola je ponovno svečano otvorena 30. listopada 1945. uz prisutnost predstavnika narodne vlasti, KPJ, masovnih organizacija i stanovništva Kastavštine. ${ }^{84}$ Da bi se zadovoljila povećana potreba za nastavnim kadrom otvorena su dva redovna razreda, dva pripravna razreda i jedan jednogodišnji tečaj. U pripravnim razredima učenici su završavali skraćeni program niže gimnazije, a u jednogodišnjem tečaju trebalo je uz skraćeni program što prije osposobiti učitelje za rad u osnovnim školama. Problemi škole bili su nedostatak udžbenika pa su nastavnici puno vremena gubili na diktiranje, nije bilo svjetla u internatu pa učenici nisu mogli učiti, nastava tjelesnoga odgoja nije održavana jer su učenici na satovima popravljali dvoranu, a nije bilo ni stakla na njezinim prozorima. Te prve školske godine nakon rata nedostajali su nastavnici za ruski jezik, gospodarstvo i crtanje, kemiju i tjelesni odgoj. Prema planu prve petoljetke, svake godine iz učiteljskih škola moralo se „izbaciti“ 6000 nastavnika i 6000 učitelja. Razredi su bili brojčano preveliki, u jednom II. razredu bilo je 67 učenika, ali se nisu mogli dijeliti jer nije bilo dovoljno nastavnika. Ako je neki nastavnik bio bolestan, nastava za te predmete nije se održavala. Da bi ipak svi slušali većinu predmeta, programi su značajno suženi. Uza školu otvorena je 1946. i vježbaonica. Kao najveći problem rada u vježbaonici navodi se da djeca ne znaju čitati,

8350 godina rada Učiteljske škole, 64. 
da ne povezuju slogove. Čak se preporučuje nastavnicima da u prvo vrijeme govore s djecom na dijalektu da bi ih ova razumjela. Puno se pozornosti polagalo metodici rada pa, da bi se poboljšao rad nastavnika, uvodi se pohađanje predavanja kolega i mjesečni planovi rada. Iduće školske godine uvedeni su ispiti sluha i obavezni liječnički pregled prije upisa učenika u školu. Usprkos poteškoćama, uspjeh učenika bio je dobar jer je „nastavni kadar dobar, a učenici su disciplinirani, borci i željni znanja“. ${ }^{85}$

Zbog nedostatka prostora i radi podizanja kvalitete rada otvara se 1947. učiteljska škola u Rijeci, a zatvara u Kastvu. Ovoga puta Kastav je ostao trajno bez učiteljske škole, u njemu je ostala samo škola za odgajateljice. U Rijeci je škola djelovala do 1963., kada je osnovana Gimnazija pedagoškog smjera. Od 1971. škola radi pod nazivom Gimnazija Vladimir Nazor, da bi konačno 1978. potpuno prestala s radom učiteljska škola jer je osnovan Centar za kadrove u obrazovanju i kulturi. Obrazovanje za učiteljstvo prebacuje se na Pedagoški fakultet, a CZKUOIK preimenovan je 1992. u Prvu riječku hrvatsku gimnaziju.

\section{Zaključna razmatranja}

Izbor Kastva za smještaj pripravnice i učiteljske škole nije bio nelogičan. U Kastvu je stanovništvo bilo gotovo u cijelosti hrvatsko i uporabni je jezik bio hrvatski. Još 1866. u Kastvu je otvoren Narodni dom i čitaonica. U Kastvu je održan i prvi tabor. Iz Kastavštine je bio i „trolist“ istarskoga nacionalnog pokreta: Vjekoslav Spinčić, Matko Laginja i Matko Mandić. Kastavska općina je osigurala sredstva za gradnju škole, što je pomoglo pri lobiranju za dobivanje škole. Kada je Kastav Rapalskim ugovorom odijeljen od Istre, našao se na periferiji Kraljevine SHS. Naglo osiromašenje stanovništva i općine uvjetovalo je da škola nije mogla pratiti standarde koje je propisivala država pa se dva puta gasila. Ta škola nije bila jedina učiteljska škola u Istri, ali djelovala je najduže, u gotovo neprekinutom kontinuitetu 41 godinu.

Iako je objavljeno nekoliko radova na ovu temu, nisu obrađeni svi aspekti niti kompleksnost povijesti obrazovanja na hrvatskom jeziku u Istri i na Kvarneru. Možda će ovaj skroman članak ukazujući na građu koju čuvaju Državni arhiv u Rijeci i Arhiv Prve riječke hrvatske gimnazije potaknuti daljnje istraživanje i proučavanje ove tematike.

85 APRHG, Knjiga Zapisnika sjednica Nastavničkoga zbora, 1946/47 - 1948/49, arh. br. 102. 


\section{Sažetak}

Članak se bavi učiteljskom školom u Kastvu. Kroz rad škole mogu se pratiti svi problemi koji postoje u društvu, promjene političkih vlasti, promjene obrazovnih sustava i ideologija. U pisanju članka korišteni su dokumenti iz Državnoga arhiva u Rijeci i arhiva Prve riječke hrvatske gimnazije koja je sljednica učiteljske škole. Podaci iz arhivskih dokumenata komparirani su s dostupnom stručnom literaturom. Prvenstveno je ideja ovoga teksta bila obraditi jedan segment rada učiteljske škole na temelju podataka iz arhivske građe, a kroz rad škole prikazati i promjene u društvu koje ju je okruživalo.

Članak je podijeljen u četiri cjeline. U prvoj se opisuje otvaranje i rad pripravnice, koja je imala zadaću pripremiti učenike za prijemni ispit na učiteljskoj školi u Kopru. Nastava se održavala na hrvatskom jeziku, pa su tako mnogi učenici prvi put slušali nastavu na materinskom jeziku. Drugi dio opisuje napore Općine Kastav da dobije i sagradi školu u Kastvu te nastavu u vrijeme Prvoga svjetskog rata. U vrijeme rata veći je dio nastavnika i učenika starijih razreda mobiliziran, a neki su učenici mlađih razreda morali odustati od školovanja zbog oskudice. Treći dio opisuje vrijeme talijanske okupacije, priključenje Kastva Kraljevini SHS te organizaciju nastave i gašenje škole 1938. U tom se razdoblju u školu počinju primati i djevojčice kao redovite učenice. U četvrtom se dijelu opisuje ponovno otvaranje škole nakon Drugoga svjetskog rata i njezin rad u neposrednom poraću sve do njezinoga konačnog premještanja 1947. u Rijeku. Nakon rata zbog državne politike brzog opismenjavanja stanovništva naglo raste broj učenika pa škola postaje premala. Kroz cijelo vrijeme rada škole, osim u vrijeme talijanske okupacije, nastava se održavala na hrvatskom jeziku. Škola je dala velik broj učitelja koji su mnogu djecu naučili čitati i pisati i to na hrvatskom jeziku.

\section{L'Istituto Magistrale di Castua nei documenti dell'Archivio di Stato di Fiume e dell'Archivio del Primo Ginnasio Croato di Fiume}

\section{Riassunto}

Il contributo tratta dell'istituto magistrale di Castua. Attraverso l'attività dell'istituto è possibile tracciare diversi problemi esistenti nella società, il cambio di governi politici, del sistema di istruzione e delle ideologie. Nella stesura dell'articolo sono state usate le fonti dell'Archivio di Stato di Fiume e dell'archivio del Primo Ginnasio Croato di Fiume, successore dell'istituto magistrale. I dati ricavati dai documenti archivistici sono stati comparati a quelli delle pubblicazioni scientifiche. L'intento di questo articolo è, in primo luogo, di occuparsi di un segmento dell'attività dell'istituto magistrale in base ai dati ricavati dal materiale archivistico e di presentare i cambiamenti accaduti nella società che lo circondava attraverso la descrizione della sua attività.

L'articolo è suddiviso in quattro parti. La prima descrive l'apertura e l'attività della scuola che doveva preparare gli allievi per l'esame di ammissione all'istituto magistrale di Capodistria. L'insegnamento si svolgeva in lingua croata in modo che molti allievi poterono, per la prima volta, seguire le lezioni nella lingua materna. La seconda parte descrive gli sforzi del Comune di Castua di otte- 
nere e costruire la propria scuola e di svolgervi le lezioni durante la Prima guerra mondiale. Durante la guerra la maggior parte degli insegnanti e degli alunni delle classi superiori fu mobilizzata, mentre alcuni alunni delle classi inferiori dovettero rinunciare all'educazione a causa della miseria. La terza parte descrive il periodo dell'occupazione italiana, l'annessione di Castua al Regno SCS, l'organizzazione dell'insegnamento e la cessazione dell'attività nel 1938. In questo periodo la scuola inizia ad accogliere le bambine come alunne regolari. Nella quarta parte è descritta la riapertura della scuola immediatamente dopo la fine della Seconda guerra mondiale e la sua attività fino al trasferimento definitivo a Fiume accaduto nel 1947. Dopo la guerra infatti, per effetto della politica statale di rapida alfabetizzazione della popolazione, aumenta repentinamente il numero degli alunni e la scuola diventa troppo piccola. Durante tutti gli anni di insegnamento svoltosi presso l'istituzione, tranne nel periodo dell'occupazione italiana, le lezioni si sono sempre tenute in lingua croata. La scuola ha fornito un grande numero di insegnanti che hanno insegnato a molti bambini a leggere e scrivere in lingua croata.

\section{School for teachers in Kastav through documents from the State Archives in Rijeka and the Archives of First Croatian Grammar School of Rijeka}

\section{Summary}

The article explores the school for teachers in Kastav. Through the school's work, one can track all problems present in the society, change of political authorities, change of educational systems and ideologies. Documents from the State's archives in Rijeka and the archive of the First Croatian grammar school in Rijeka, the successor of the school for teachers, were used. The records from the archives are compared with the literature available. The first idea of this text was to cover just one segment of the school's work based on the information from the archives, and to show the changes in the society through the school's work.

The article is divided into four parts. The first describes the founding and work of the intern which had the task of preparing the students for the admission's exam for the school for teachers in Koper (Capodistria). The lectures were in Croatian so many students attended the classes with their mother tongue for the first time. The second part describes the efforts of Kastav County to get and build a school in their town during First World War. During the war, most of the teachers and older students were drafted, and some younger students had to leave school due to hard times. The third part describes the Italian occupation, Kastav joining Kingdom of SHS and organizing classes and the subsequent cancelling the school in 1938. During that period the school started accepting girls as regular students. The fourth part describes the reopening of the school after Second World War and its work after the war, up until its move to Rijeka in 1947. After the war, due to the state's policy of literacy, the number of students rose, and the school became too small as a result. During the entire time the school was opened, except during the Italian occupation, the classes were in Croatian. The school educated many teachers who taught many children how to read and write in Croatian. 


\section{Prilozi}

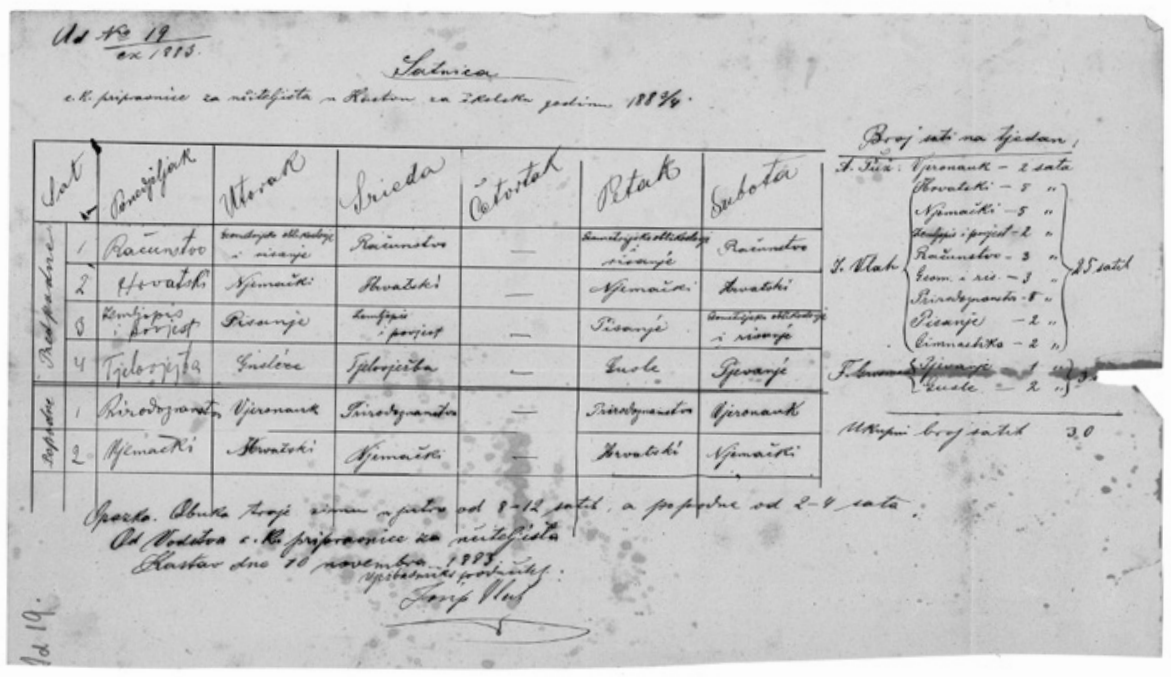

Sl. 1. Najstariji sačuvani raspored sati kastavske C. i kr. pripravnice za učiteljišta za školsku godinu 1883./1884. (Arhiv PRHG-a)

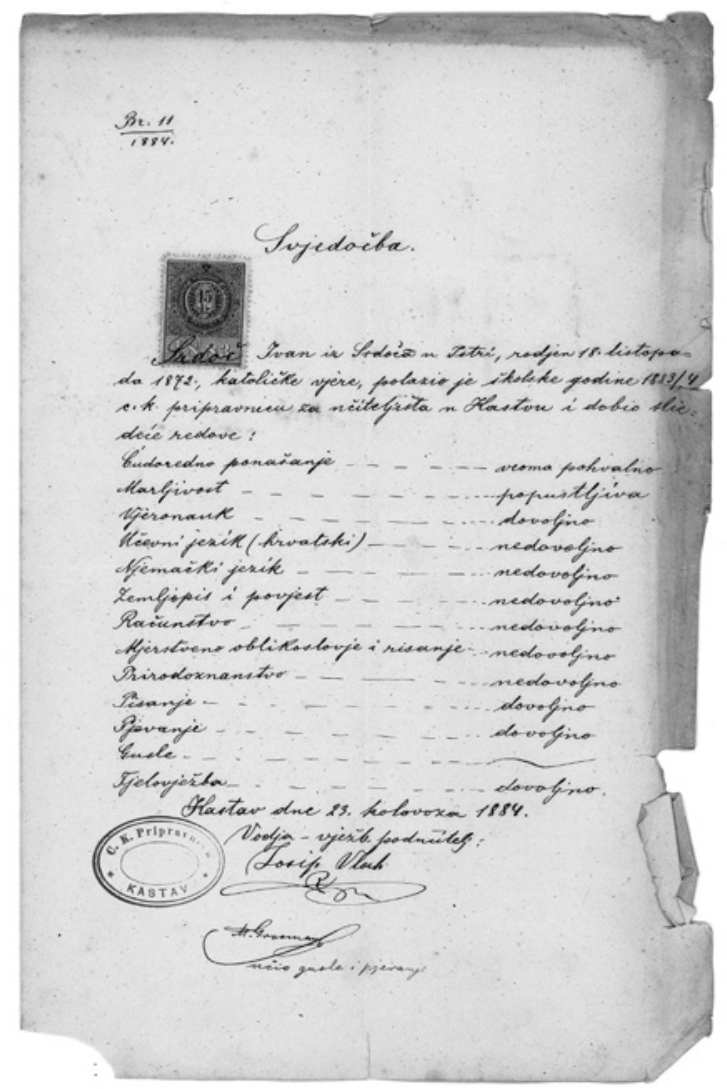

Sl. 2. Svjedodžba kastavske C. i kr. pripravnice za učiteljišta (svjedodžba Ivana Srdoča) iz 1884. (Arhiv PRHG-a) 


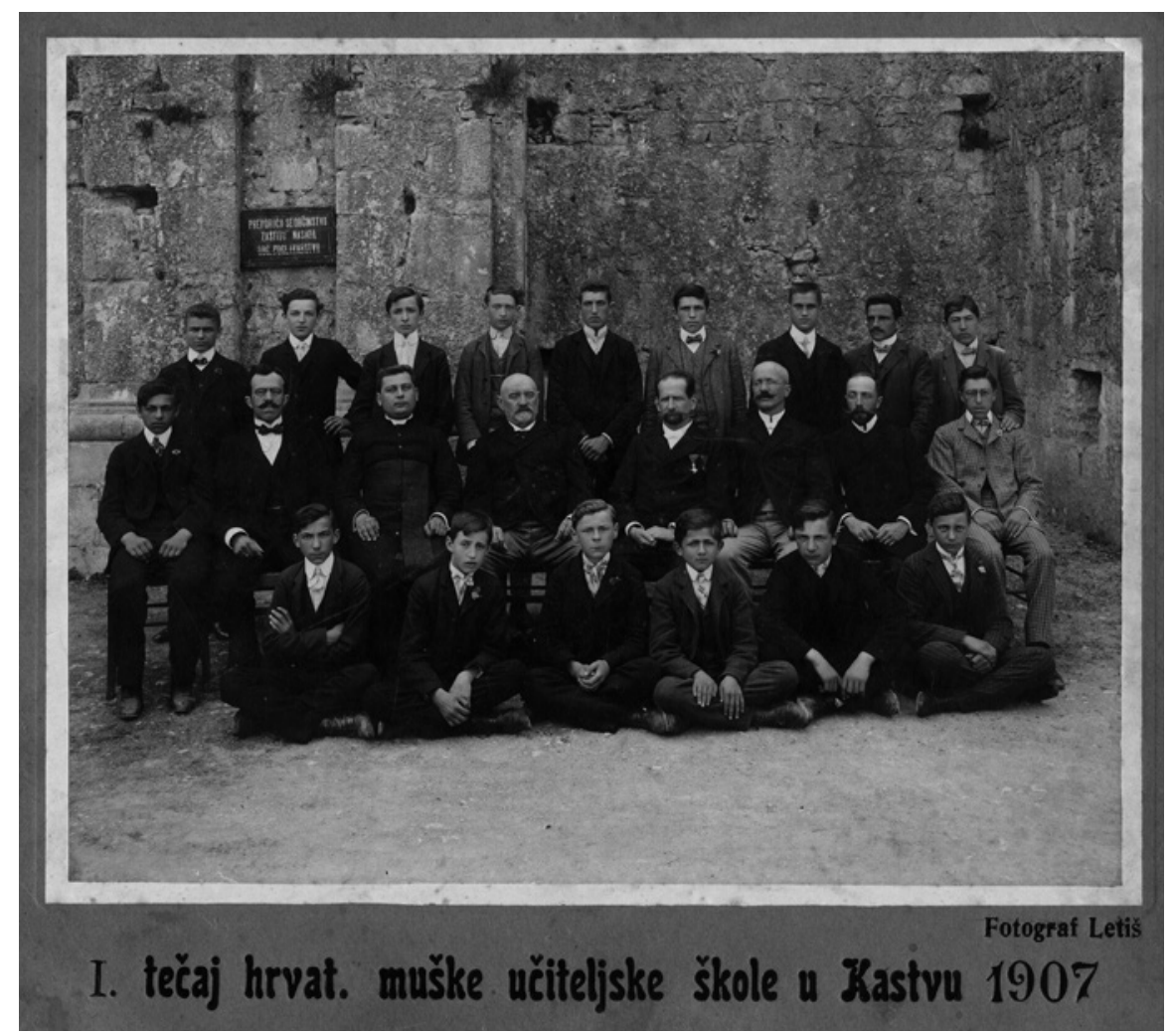

S1. 3. Prvi naraštaj Učiteljske škole u Kastvu (Arhiv Pomorskog i povijesnog muzeja Hrvatskog primorja, Rijeka)

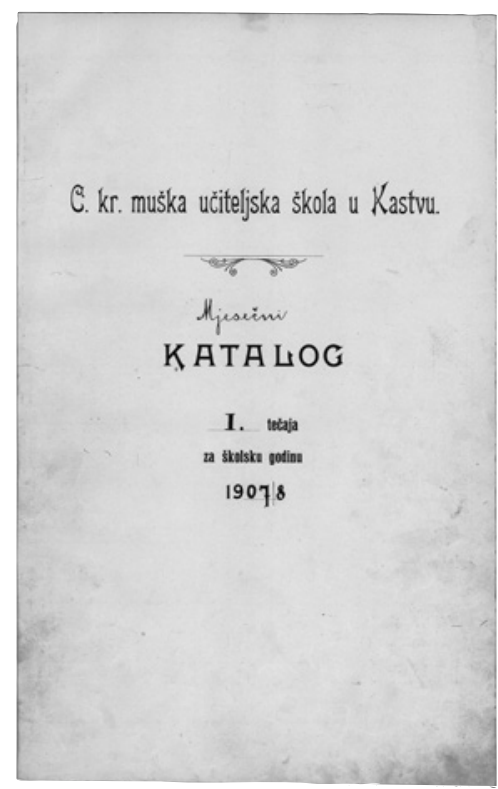

S1. 4. Naslovnica mjesečnoga kataloga 1. naraštaja za školsku godinu 1907./1908. - tadašnji imenik u kojem se nalaze podaci o učenicima, njihove ocjene i primjedbe učitelja (Arhiv PRHG-a) 


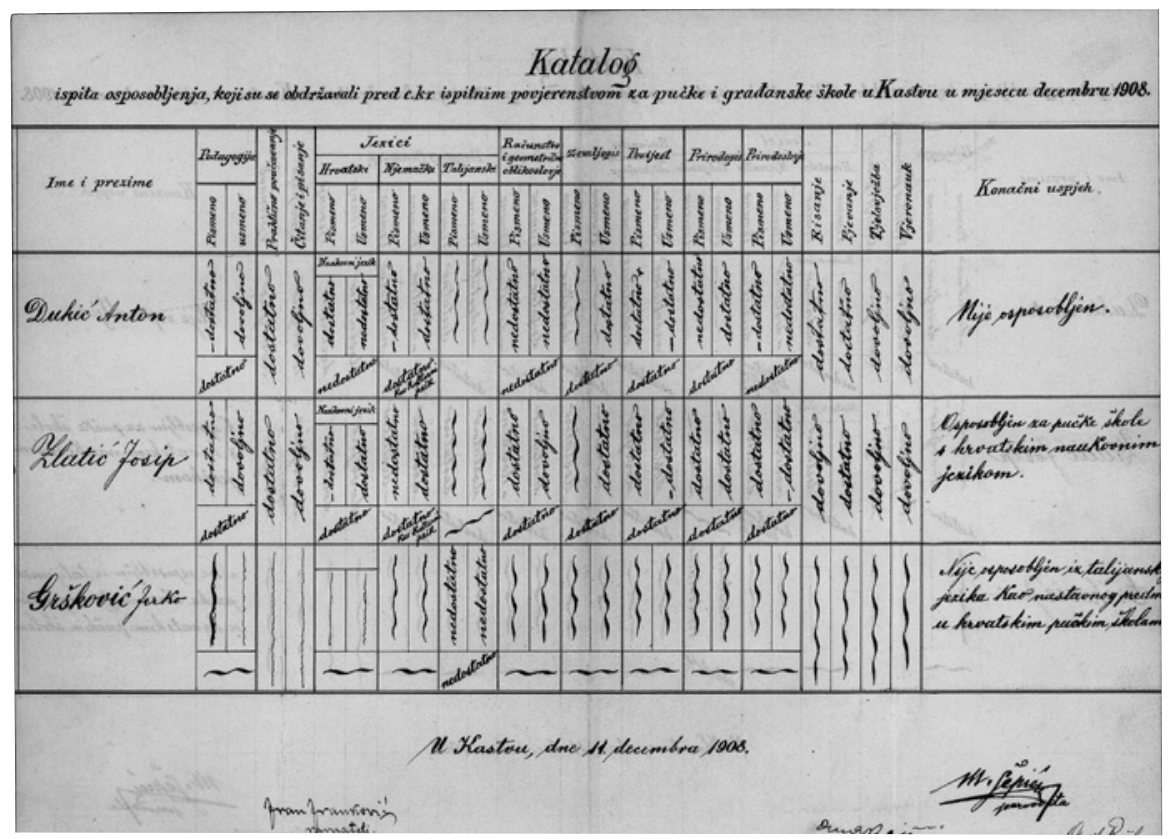

Sl. 5. Katalog ispita osposobljenja iz 1908. (Arhiv PRHG-a)

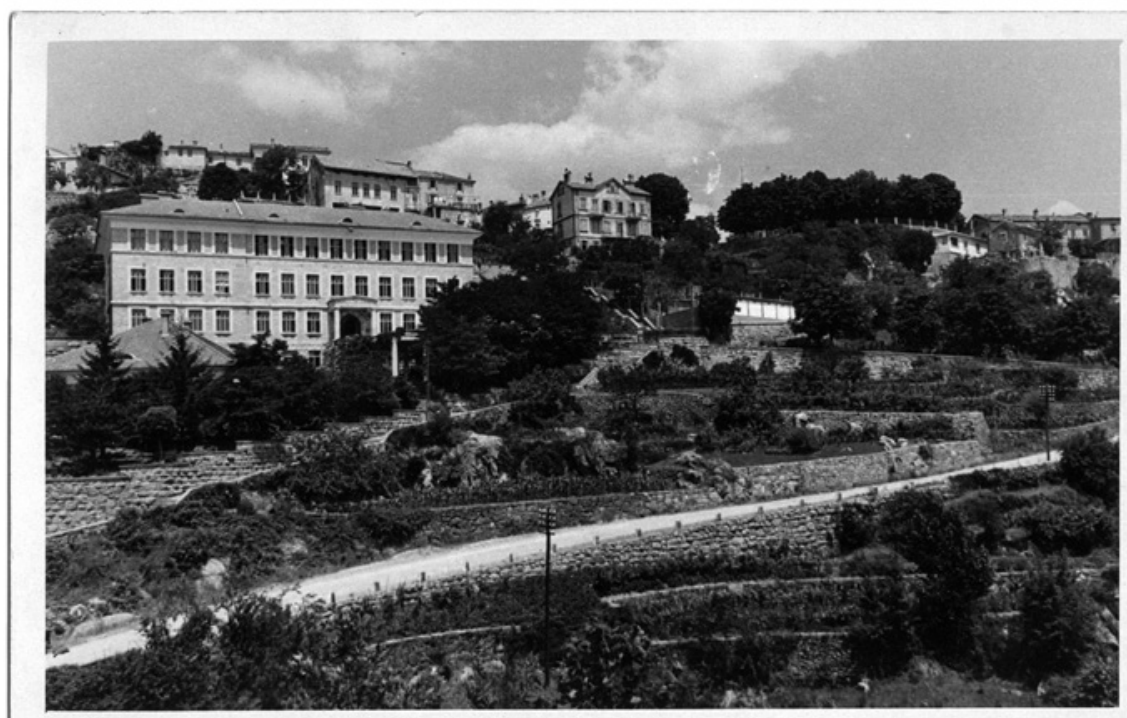

Sl. 6. Nova Učiteljska škola kralja Aleksandra (Arhiv Pomorskog i povijesnog muzeja Hrvatskog primorja, Rijeka) 


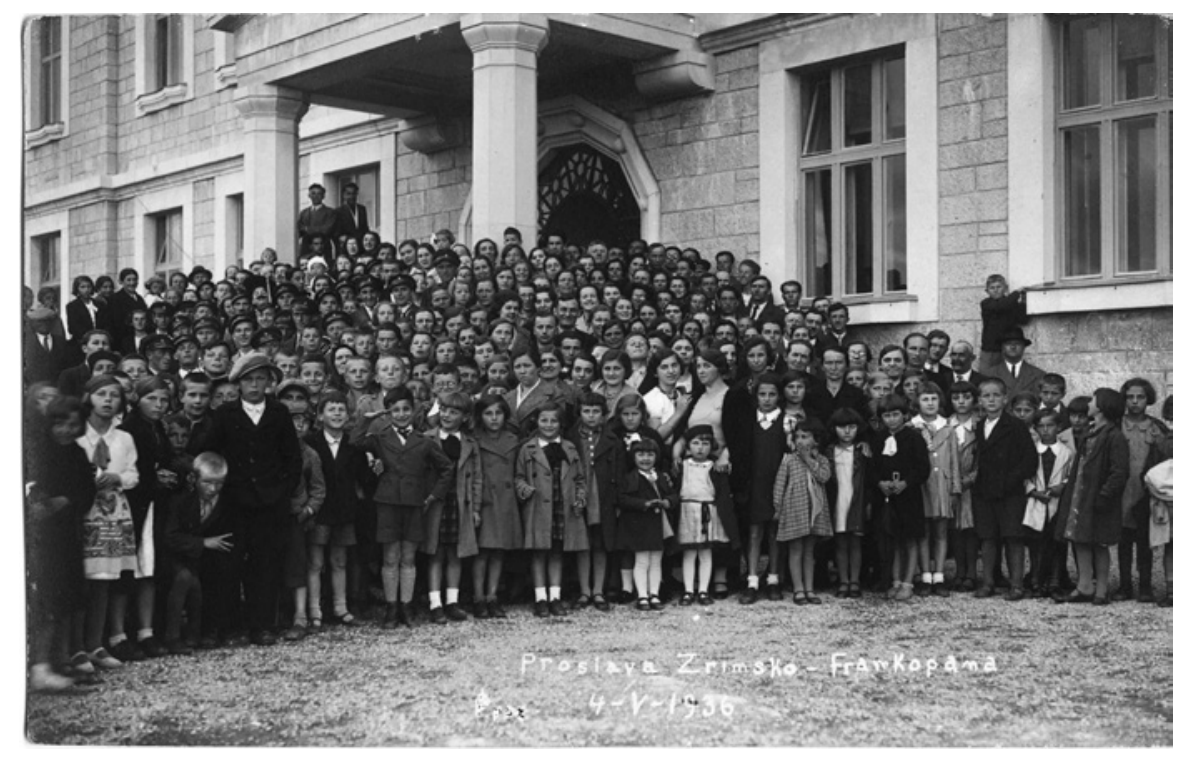

Sl. 7. Svečanost obilježavanja obljetnice pogubljenja Zrinskoga i Frankopana 1936. - nema podataka tko je na fotografiji, ali je po svemu sudeći riječ o učenicima Učiteljska škole i učenicima Vježbaonice (Arhiv Pomorskog i povijesnog muzeja Hrvatskog primorja, Rijeka)

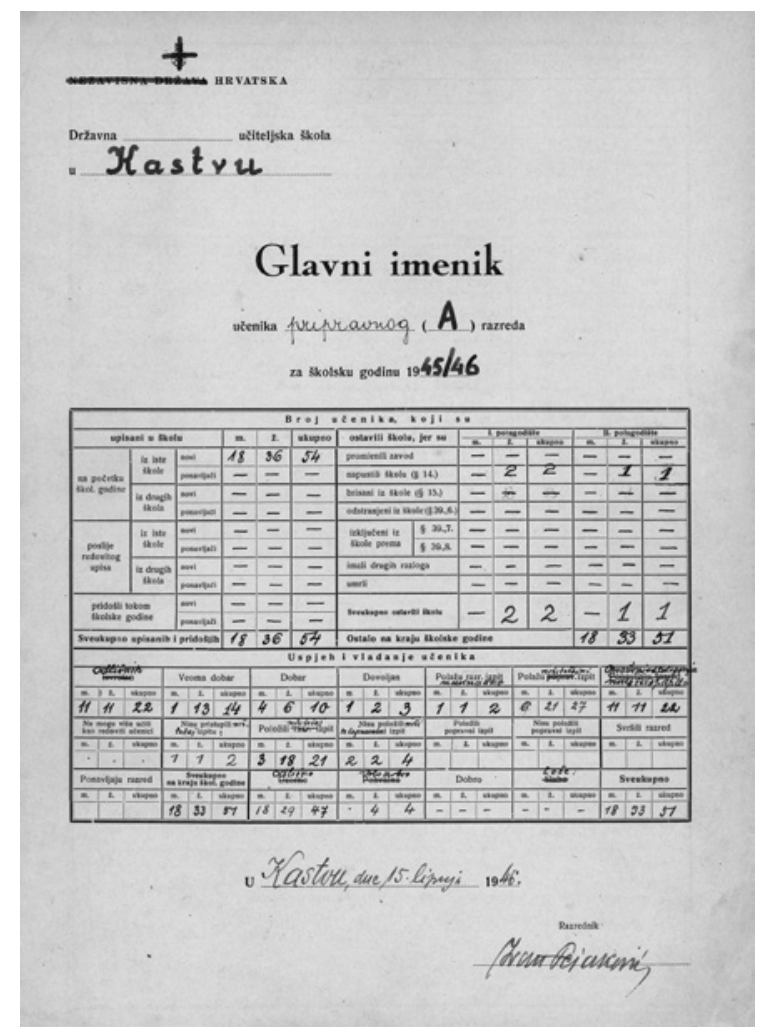

Sl. 8. Prvi imenik nakon Oslobođenja za školsku godinu 1945./ 1946. (Arhiv PRHG-a) 
